\title{
Highlights
}

- Shale gas and coal-bed methane show remarkably similar opportunities for the in situ stimulation of microbial methane generation.

- The vast literature available from bioremediation studies can significantly improve our understanding of microbial processes in unconventional gas systems.

- Engineering technologies such as hydraulic fracturing may be adapted to stimulate biogenic gas production and favour positive microbial processes.

- Managing microbial communities in unconventional gas systems have implications for both recovery practices and a sustainable development of unconventional resources. 


\section{Biogenic methane in shale gas and coal bed methane: a review of current 2knowledge and gaps}

3Fabrizio Colosimo ${ }^{\mathrm{a}, *}$, Russell Thomas ${ }^{\mathrm{b}}$, Jonathan R Lloyd $\mathrm{d}^{\mathrm{c}}$, Kevin G Taylor ${ }^{\mathrm{c}}$, Christopher Boothman ${ }^{\mathrm{c}}$, 4Anthony D Smith ${ }^{\mathrm{d}}$, Richard Lord ${ }^{\mathrm{a}}$ and Robert M Kalin ${ }^{\mathrm{a}}$

6ªpartment of Civil and Environmental Engineering, University of Strathclyde, 75 Montrose Street,

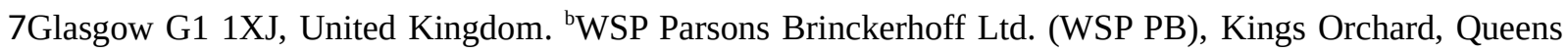
8Street, Bristol BS2 OHQ, United Kingdom. 'Williamson Research Centre for Molecular Environmental 9Science, School of Earth, Atmospheric and Environmental Sciences, The University of Manchester, Oxford

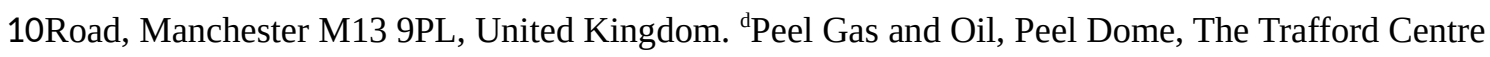
11Manchester M17 8PL. ${ }^{*}$ To whom correspondence should be addressed at: email: 12fabrizio.colosimo@strath.ac.uk. Tel: +44(0)7446898984.

13

\section{Abstract}

15Biogenic $\mathrm{CH}_{4}$ generation has been observed in many shallow, low temperature shale gas 16basins and coal seams. The depletion of conventional resources and the increasing demand of 17natural gas for human consumption have spurred the development of so-called 18unconventional gas resources such as shale gas (SG) and coal-bed methane (CBM). Such 19unconventional systems represent the opportunity for the stimulation of biogenic $\mathrm{CH}_{4}$ 20generation. Biogenic $\mathrm{CH}_{4}$ in shale and coal is produced by anaerobic biodegradation of 21organic matter (OM): methanogenic Archaea represent only the final step of biogenic $\mathrm{CH}_{4}$ 22generation. Several communities of microorganisms are involved in the initial breakdown of 23complex geopolymers and the production of intermediate compounds used by methanogens. 24There are several key knowledge gaps on biogenic $\mathrm{CH}_{4}$ production in unconventional gas 25systems, such as the exact fraction of bioavailable OM, the microbial communities involved 26and how they can be stimulated to enhance microbial methanogenesis. Progress on 27biodegradation studies, isotopic signatures, as well as DNA analyses and proteomics could 
28help unravel interactions within the syntrophic community involved in the methanogenic 29biodegradation of OM. Questions also remain regarding the environmental impact of 30unconventional gas production, such as water quality and the mobility of toxic metals and 31radionuclides. The answers to these questions might have implications for both recovery 32practices and a sustainable development of unconventional resources. This review 33summarises the current knowledge regarding biogenic $\mathrm{CH}_{4}$ in $\mathrm{SG}$ and $\mathrm{CBM}$ : from the nature 34of the rocks to the producing microbial community and the indicators of biogenic $\mathrm{CH}_{4}$, 35illustrating how these two environments show remarkably similar opportunities for the 36stimulation of biogenic $\mathrm{CH}_{4}$ generation.

37

\section{Keywords}

39Shale gas; Coal-bed methane; Microbial methane; Organic matter; Biodegradation. 


\section{Introduction}

41

42In recent decades, unconventional gas production from fractured shales and coal seams has 43experienced a rapid development in many parts of the world (Pearson et al., 2012). The 44success of SG and CBM is linked to the increasing demand of natural gas and the progressive 45depletion of conventional gas resources (McIntosh et al., 2008). Historically, the first 46extraction of SG began in Fredonia, Pennsylvania in the USA in 1821, in shallow, low47pressure fractures (Peebles, 1980; Trembath et al., 2012). Similarly, CBM was first extracted 48in the USA in the late 1930s, but economic production started in 1980s, when the United 49States Congress enacted a tax credit for "Non-conventional energy" production (US EPA 501994). Both SG and CBM industries have experienced rapid growth during the past 20 years, 51thanks to significant advances in extraction technologies (Jenkins and Boyer II, 2008). The 52combination of horizontal drilling and hydraulic fracturing has allowed access to large 53volumes of SG that were previously uneconomical to extract (Yang et al., 2014). SG wells 54typically produce significantly more gas per well, but cost substantially more to drill than 55CBM wells (Ritter et al., 2015). In spite of the large use of hydraulic fracturing, very little is 56known about the microbiological implications of this process. Hydraulic fracturing is a well57established technology to increase the permeability of a formation and, together with other 58stimulation strategies, could be applied in situ to achieve or maintain optimised conditions for 59microbial activity. Stimulation strategies could be used to enhance the productive lifespans of 60depleted microbial SG and CBM wells, extending and/or regenerating biogenic $\mathrm{CH}_{4}$ 61production. Ex situ treatments could involve the use of wastewater and coal/shale waste 62materials to produce $\mathrm{CH}_{4}$ and reduce the environmental impact of SG and CBM production. 63This review is not intended to be an exhaustive review of biogenic $\mathrm{CH}_{4}$ generation, it rather 64describes the current knowledge of biogenic $\mathrm{CH}_{4}$ generation in shales and coals, illustrating 
65the analogies and differences of the two environments, and focusing on biodegradation 66process of complex OM. We also demonstrate how the vast literature available from 67bioremediation studies can significantly improve our understanding of microbial processes in 68unconventional gas systems. Lastly, we present the current knowledge about enhanced 69biogenic $\mathrm{CH}_{4}$ generation in SG and $\mathrm{CBM}$ basins, pointing out how current engineering 70technologies may be adapted to stimulate biogenic $\mathrm{CH}_{4}$ production and favour positive 71microbial processes.

72

732. Biogenic $\mathrm{CH}_{4}$ in unconventional gas basins

74

752.1. Generation and accumulation of $\mathrm{CH}_{4}$ 
76The advances of biogeochemical studies on organic-rich sedimentary rocks and gas isotopic 77analysis, have allowed a better understanding of the origin of $\mathrm{CH}_{4}$ in the subsurface. These 78studies highlighted the microbial or mixed origin of $\mathrm{CH}_{4}$ in both coal beds (Faiz and Hendry, 792006; Scott et al., 1994; Zhou et al., 2005; Kinnon et al., 2010; Hamilton et al., 2014 and 802015; Baublys et al., 2015) and shales (A. M. Martini et al., 1996; McIntosh et al., 2008; 81Schlegel et al., 2013, 2011a) in many parts of the world (Fig. 1). Early estimations of 82 microbial gas suggest that approximately $20 \%$ of total natural gas production in the world is 83biogenic (Rice and Claypool, 1981), and an additional 10\% of the gas resources may also be 84of microbial origin (Grunau, 1983). In general, $\mathrm{CH}_{4}$ in shale and coal beds, is generated from $85 \mathrm{OM}$, sourced from the remains of organisms deposited as fine particles in sedimentary rocks, 86along with the mineral grains that constitute such rocks. Microbial methanogenesis in 87unconventional gas systems is a multi-step, syntrophic process that involves a consortium of 88bacteria and methanogenic Archaea. Bacteria break down complex OM into intermediate 89compounds (e.g. long chain fatty acids, alkanes, and low molecular weight aromatics; Orem 90et al., 2010), which are then biodegraded into substrates that are converted by methanogens 91(e.g. acetate, $\mathrm{CO}_{2}$ and $\mathrm{H}_{2}$, methanol, formate; Strapoc et al., 2011) into $\mathrm{CH}_{4}$. Typically, all 920ther potential electron acceptors (e.g. ferric iron and sulfate) must be exhausted before 93microbial methanogenesis will proceed (Claypool and Kaplan, 1974; Kuivila et al., 1988; 94Mah et al., 1977; Martens and Berner, 1974; Reeburgh and Heggie, 1977). 
95OM is first converted to $\mathrm{CH}_{4}$ by bacterial processes (primary biogenic $\mathrm{CH}_{4}$ ), and later by high 96temperatures and pressures as the sedimentation proceeds (thermogenic $\mathrm{CH}_{4}$ ) (Jones et al., 972008). Further episodes of microbial methanogenesis are often observed after meteoric 98recharge of water or other geological events (secondary biogenic $\left.\mathrm{CH}_{4}\right)(\mathrm{Milkov}, 2011)$. After 99generation, the gas rises upward through the pore system, until it encounters a trap such as an 100impermeable rock, forming a conventional reservoir. However, some of the gas generated 101during thermogenic and biogenic process, remains trapped in the fine grained source rock 102(e.g. shales and coals), forming unconventional basins (Pearson et al., 2012).

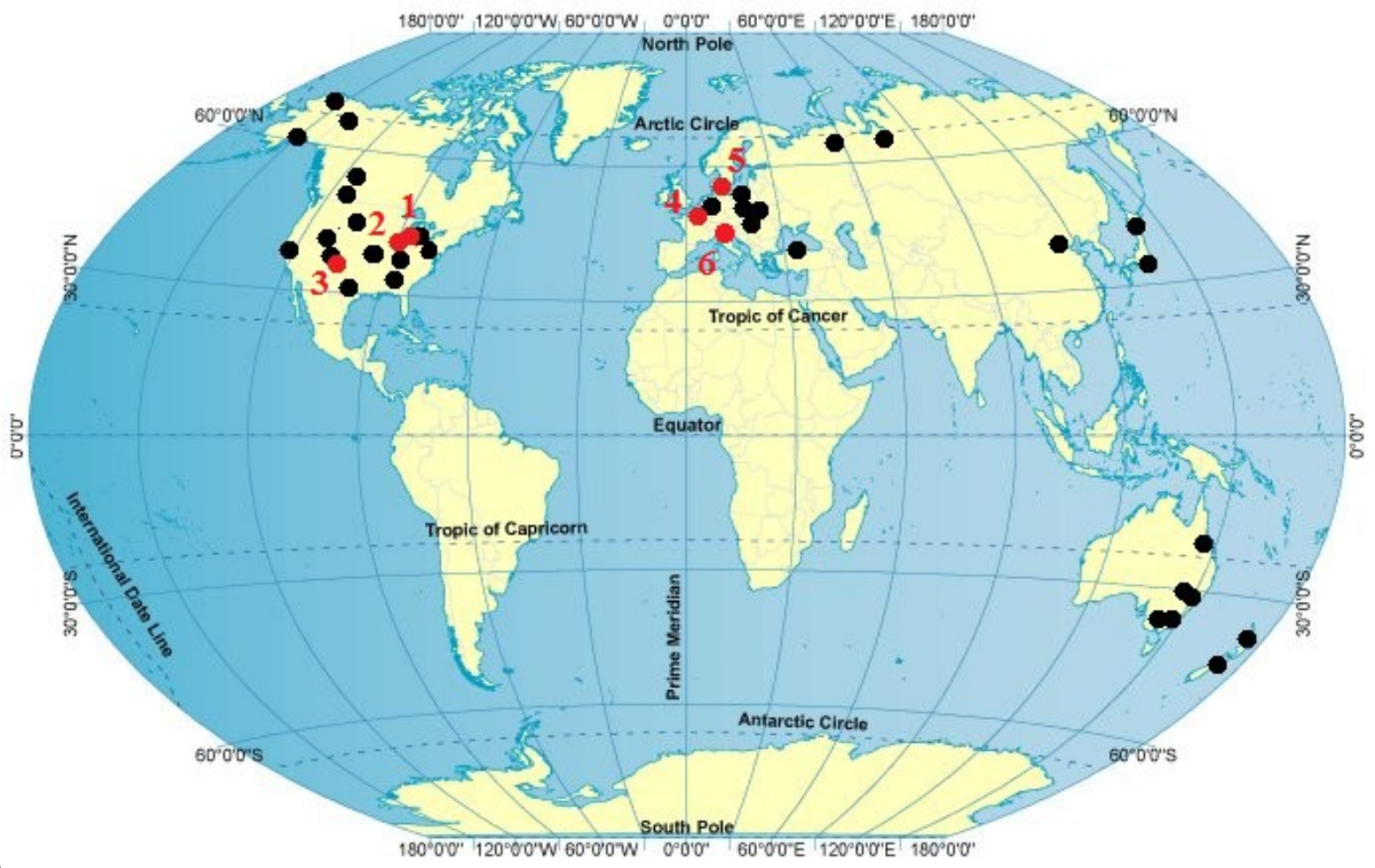

105Fig. 1. World map showing locations where biogenic $\mathrm{CH}_{4}$ from CBM (black circles) and SG (red circles) has 106been observed. For CBM basin names and references, see Strąpoć et al., (2011) and Ritter et al., (2015). For SG: 107(1) Antrim shale (Martini et al., 1996, 1998, 2003). (2) New Albany shale (Martini et al., 2008; McIntosh et al., 1082010; Schlegel et al., 2011a, 2011b; Strąpoć et al., 2010). (3) Cretaceous Mancos shale (L. R. Krumholz et al., 1091997). (4) Eastern Paris Basin (Meslé et al., 2015). (5) Alum shale (Krüger et al., 2014). (6) Po basin (Mattavelli 110et al., 1992). 


\subsection{Gas storage}

113The gas generated through thermogenic or biogenic process is stored in three modes (Curtis 114et al., 2002): (i) free gas in intergranular porosity and natural fractures, (ii) adsorbed gas onto 115kerogen and inorganic minerals and (iii) dissolved gas in water, kerogen and bitumen. 116Characterisation of porosity and pore size distribution is particularly important when 117considering biogenic $\mathrm{CH}_{4}$ production, since a major constraint to microbial colonisation of 118organic-rich rocks would be the limited space available, as well as the contact surface area of 119microorganisms with OM. There are several challenges in establishing a relationship between 120the presence and activity of microorganisms and physical properties of the host rocks, such as 121the pore size, pore size distribution and permeability. Fig. 2 shows the three modes of gas 122storage and the main transport mechanisms from the source rock to production well. Pores in 123solid material can be divided in: (i) macropores (>50 nm), (ii) mesopores (2-50 nm), and (iii) 124micropores (or nanopores) $(<2 \mathrm{~nm})$ (Rouquerolt et al., 1994). This classification is 125particularly important for unconventional basins since a significant portion of gas is sorbed 126onto the surfaces of mesopores and micropores (Ross and Bustin, 2009). It has been 127hypothesised that the primary role of macro- and mesopores is to act as a transport conduits 128(Moore, 2012). Micropores play a significant role in $\mathrm{CH}_{4}$ adsorption, typically contributing 129the most to the total surface area, as demonstrated for both coal (Beliveau, 1993; Mastalerz et 130al., 2008) and shale (Chalmers and Bustin, 2007; Ross and Bustin, 2009). Gas storage has 131long been studied for CBM, identifying a number of factors that influence gas sorption 132process, including maceral type (Lamberson and Bustin, 1993), ash content (Laxminarayana 133and Crosdale, 1999), rank (Levine, 1996; Bustin and Clarkson, 1998), moisture (Levy et al., 1341997) and temperature (Bustin and Clarkson, 1998). In unconventional gas systems, most of 135the $\mathrm{CH}_{4}$ is adsorbed (Milewska-duda et al., 2000), therefore pore surface area rather than pore 
136volume is the most crucial factor for gas storage (Moore, 2012). The pore surface area is 137directly correlated to the pore size distribution. As pore size decreases, the ratio of free gas to 138sorbed gas storage capacity decreases (Bustin et al., 2008). In general, for pores less than 0.01 $139 \mu \mathrm{m}$, the sorbed gas component exceeds the free gas storage (Beliveau, 1993). Micropores in 140shale formations contribute the most to the total surface area, as observed by porosimetry in 141the Haynesville, Marcellus and Doig shales (Chalmers et al., 2012). Macropores and 142mesopores in these formations are associated with either kerogen and clay aggregates or 143kerogen and carbonate aggregates (Chalmers et al., 2012). The association between 144mesopores and micropores with kerogen has been identified in both CBM and SG studies 145(Chalmers and Bustin, 2008, 2006; Clarkson and Bustin, 1996; Larsen et al., 1995; Marsh et 146al., 1985; Unsworth et al., 1989). Interconnection between pores of different size and 147fractures is an important control on the matrix permeability, which influence $\mathrm{CH}_{4}$ transport 148(Chalmers et al., 2012). In tight source rock, $\mathrm{CH}_{4}$ transport occurs by different mechanisms 149depending on the flow and porous formation conditions (Civan et al., 2011; Roy et al., 2003). 150Flow in the fractures is controlled by advection and is modelled using Darcy's law. Within the 151micropores, transport mechanisms include diffusion (molecular flow) and advection (Darcy 152flow) (Schlömer and Krooss, 1997). Simple Darcy’s law based analyses and interpretation are 153insufficient to characterise permeability and diffusivity of gas in shale (Civan et al., 2011). In 154fact, at the nanometer scale, the Darcy's law is no longer applicable: flow in the nanopore 155matrix is controlled by diffusion, molecule-molecule and molecule-pore wall interactions 156(Bustin et al., 2008; Javadpour, 2009; Schettler et al., 1989). In organic-rich rocks, 157microporosity is often correlated with total organic carbon (TOC) (Chalmers and Bustin, 1582007; Passey et al., 2010), the organic fraction of shale and coal is an important control on 159 $\mathrm{CH}_{4}$ storage, as demonstrated by positive correlations between TOC and sorbed gas (Gasparik 160et al. 2013; Ross and Bustin, 2009, 2007; Chalmers and Bustin, 2008). During thermal 
161maturation, the decomposition of OM leads to the production of hydrocarbons and allows the 162formation of intraparticle organic pores, as observed for coal (Bustin and Clarkson, 1998; 163Laxminarayana and Crosdale, 1999; Levy et al., 1997) and shale (Chalmers et al., 2012; 164Chalmers and Bustin, 2007; Jarvie et al., 2007). In general, at higher thermal maturity, the 165diagenesis transforms OM, creating more microporosity and decreasing the heterogeneity of 166the pore surface (Levy et al., 1997). This process was often observed in high rank coal, where 167usually there is a high sorbed gas capacity (Bustin and Clarkson, 1998). The correlation 168between nanopore abundance in grains of OM and Vitrinite Reflectance (VRo) is consistent 169with observation made by Hover et al., (1996). They found no visible intercrystalline or 170intraparticle matrix porosity for low thermal-maturity rocks of the Antrim and New Albany 171shales. Such conclusions were also supported in a study of Cretaceous shales (Chalmers and 172Bustin, 2007) where the highest $\mathrm{CH}_{4}$ sorption was observed in samples with highest 173concentrations of inertodetrinite and vitrinite. For thermally immature Jurassic shales, no 174relationship between TOC and micropore volume or surface area was found (Ross and 175Bustin, 2009), indicating that surface area alone is not the only factor controlling $\mathrm{CH}_{4}$ 176capacity. A component of solute $\mathrm{CH}_{4}$ within the internal structure of the matrix bituminite was 177proposed as a dominant mechanism of gas storage in Jurassic shales (Ross and Bustin, 2009). 178In CBM, gas content increases with depth and coal rank (Scott, 2002). The relationship 179between macropores and carbon content is inversely proportional: macropores decrease and 180micropores increase with rank, with an unexpected increasing number of macropores at low 181volatile bituminous rank (Levine, 1996). In general, OM is a primary control on gas 182adsorption: the higher the TOC content, the greater the gas-sorption rates in organic-rich 183sedimentary rocks (Zhang et al., 2012). Higher gas content values are typically associated 184with higher rank coals in many reservoirs: for example, gas content in the Piceance Basin 185show an overall increase in gas content with increasing rank (Scott, 2002). These results were 
186confirmed for low and high rank coal and for organic-rich shales of different origin 187(Chalmers and Bustin, 2007). With increasing coalification, thermal cracking of n-alkanes, 188waxes, and other hydrocarbons not only generates thermogenic methane but increases 189methane adsorptive capacity by unplugging pores, resulting in higher sorption capacity and 190gas content values since methane accessibility to the micropore network is improved (Scott, 1912002). Controversially, in the San Juan Basin, lower rank coals have higher gas contents than 192higher rank coals (Scott, 2002). In this hydrogeological settings, weathering process 193introduced bacteria into the coal beds that produced secondary biogenic gases by 194metabolizing wet gases, n-alkanes, and other hydrocarbons generated during coalification 195(Scott, 2002). The generation of secondary biogenic gases increases gas contents beyond that 196expected from coal rank and if generated in sufficient quantities can actually resaturate the 197coal to the sorption isotherm (Scott et al., 1994). Overall, despite the similarities between 198shale and coal, the direct comparison of sorption characteristics of the two rocks is 199complicated by factors such as type and amount of OM, the mineral composition, pore 200volume and pore size distribution (Ross and Bustin, 2009). The controls on resource volume 201and productivity in SG reservoirs are similar to those in CBM, although SG reservoirs 202typically have lower permeability (with values in the nano- to microdarcy range), are thicker 203(30 to $300 \mathrm{ft}$ ), have lower sorbed-gas content ( $<10 \mathrm{~m}^{3} /$ tonne), and contain a larger volume of 204free gas in the pore space (Jenkins and Boyer II, 2008). Of note is that although most of the 205pores in SG and CBM basins seem to be too small to host microbial life, evidences of 206microbial activity come from enrichment and isotope experiments (Martini et al., 1996 and 2071998; Krumholz et al., 2002; Formolo et al., 2008; Kinnon et al., 2010; Hamilton et al., 2014 208and 2015; Baublys et al., 2015). 


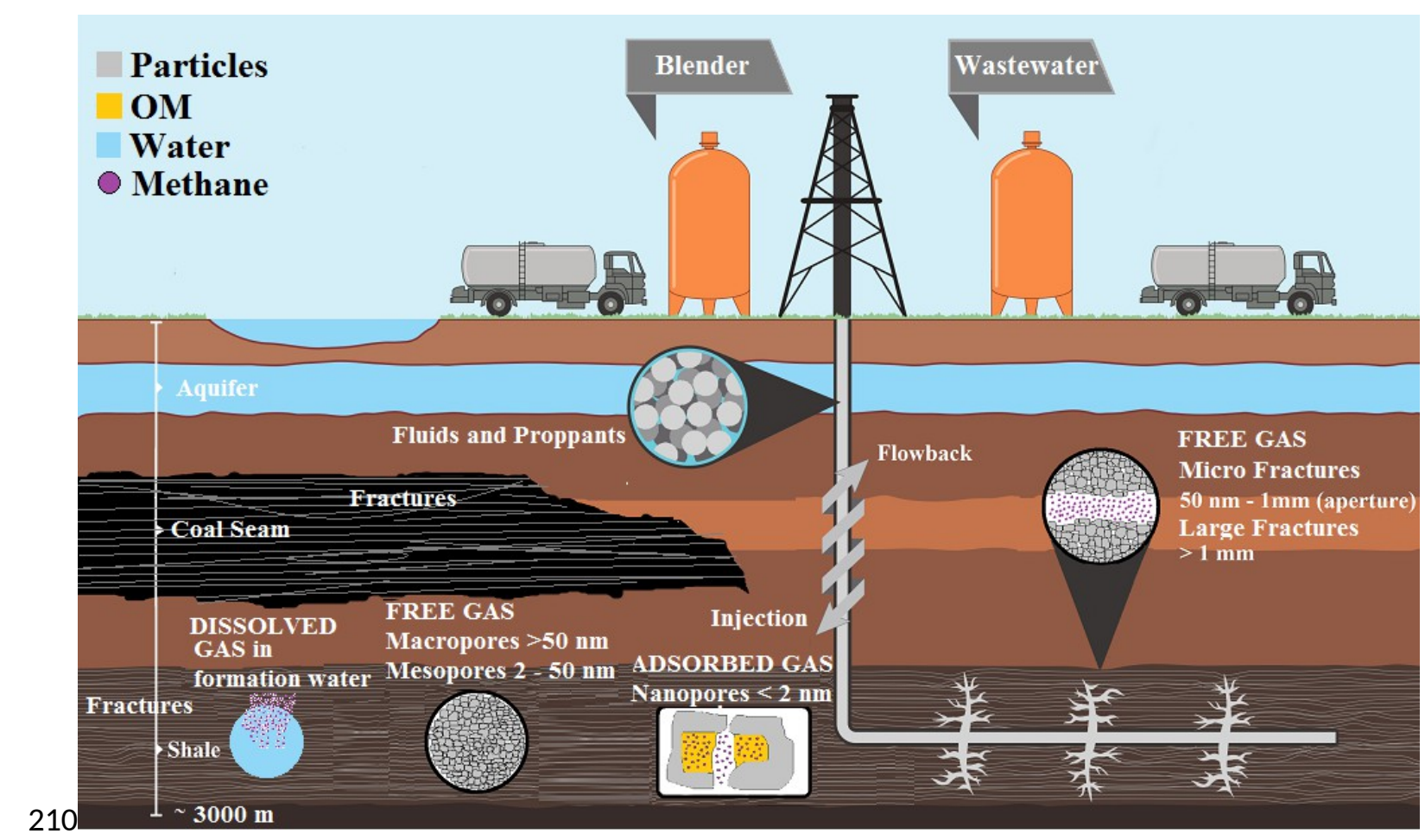

211Fig. 2. Storage and transport of gas in a SG/CBM basin from $\mathrm{CH}_{4}$ trapped in nanopores, mesopores, macropores, 212microfractures and large fractures to the production well. 


\section{Microbial ecology of SG and CBM}

215The first evidence of active, microbial populations in deep sediments was reported about 30 216years ago, when microbial activity was observed in sediment depths of about $150 \mathrm{~m}$ in the 217framework of the Deep Sea Drilling Program (DSDP) (Oremland and Polcin, 1982; Tarafa et 218al., 1987; Whelan et al., 1986). In the past decades, the existence of prokaryotes in deep 219continental sedimentary rocks was proven (Pedersen, 2000) at up to 2800m. It has been 220suggested that the biomass into the deep biosphere constitutes one-tenth (Parkes et al., 2000), 221or even one-third (Whitman et al., 1998) of the total global, living biomass. The capabilities 222of the subsurface microbial communities to convert shale and coal $\mathrm{OM}$ to $\mathrm{CH}_{4}$ was proved in 223laboratory (Fallgren et al., 2013; Jones et al., 2010, 2008; Warwick et al., 2008) and field 224studies (see Luca Technologies Inc. and Ciris Energy websites). The pathways of 225biodegradation of OM are microbially and biochemically complex (Jones et al., 2010), are 226site-specific, and could involve several communities of hydrocarbon degraders, fermenters 227and methanogenic Archaea. DNA-based assessment of the microbial community structure in 228unconventional gas basins have shown that bacterial diversity is higher than archaeal 229diversity (Barnhart et al., 2013; Penner et al., 2010; Green et al., 2008). The chemical 230complexity of OM requires the syntrophic cooperation of these microorganisms. Syntrophic 231metabolism accounts for much of the carbon flux in methanogenic environments (Schink and 232Stams, 2006). Our understanding of the intermediary ecosystem metabolisms (Drake et al., 2332009) is limited. Bacteria related to Proteobacteria (mostly Beta, Delta and 234Gammaproteobacteria), Actinobacteria, Bacteroidetes and Firmicutes seem to be widespread 235in CBM (Green et al., 2008; Jones et al., 2008 and2010; Li et al., 2008; Strapoć et al., 2008; 236Robbins et al., 2016; Warwick et al., 2008) and SG (Meslé et al., 2015, and 2013; 237Struchtemeyer and Elshahed, 2012). These taxonomic groups are known for their versatile 
238metabolic activity and hydrocarbon degrading capabilities. The archaeal diversity in shale 239and coal is usually dominated by methanogens from the orders Methanosarcinales, 240Methanomicrobiales and Methanobacteriales (An et al., 2013; Meslé et al., 2013; Fichter et 241al., 2012; Kirk et al., 2012).

242

\subsection{Actinobacteria}

244Actinobacteria are common in soil and sediments environments, and might play a central role 245in the decomposition of OM. Within the Actinobacteria, the Actinomycetales and the 246Rubrobacterales (Prince et al., 2010) possess known hydrocarbon-degrading capabilities. 247Strains of Gordonia, Mycobacterium, and Rhodococcus are able to remove sulfur from 248dibenzothiophene, yielding hydroxybiphenyl (Mohebali and Ball, 2008). Actinobacteria are 249typically aerobic hydrocarbon-degraders, but their role in anaerobic OM degradation remains 250unknown (Meslé et al., 2013). Metagenomic studies have also identified high proportions of 251genes for enzymes involved in aerobic hydrocarbon metabolism in CBM produced water 252samples (An et al., 2013), suggesting that the sequential degradation of complex OM causes 253the partial dominance of a group of microorganism in a given interval. Other studies, for 254example, reported that in anoxic environment the operation of different redox conditions is 255not mutually exclusive (Lovley et al., 1991) or cannot be explained satisfactorily by a simple 256microbial competition (Conrad et al., 1987).

\section{7}

\subsection{Bacteroidetes}

259Bacteroidetes are commonly found in sediments, and their metabolism is 260chemoheteroorganotrophs. Many of such organisms can degrade macromolecules such as 261protein, chitin, pectin, agar, starch, or cellulose. Many others are thought to be involved in oil 262biodegradation (Stra et al., 2008). Species within Cytophaga are mesophilic anaerobes able to 
263ferment polysaccharides into acetate, propionate, succinate, $\mathrm{H}_{2}$ and $\mathrm{CO}_{2}$ (Haack and Breznak, 2641993). The genus Petrimonas is mesophilic anaerobic fermenter, use carbohydrates and 265volatile fatty acids (VFAs) releasing acetate, $\mathrm{H}_{2}$ and $\mathrm{CO}_{2}$ (Grabowski et al., 2005). Within the 266Prolixibacter there are acid fermenters that produce propionate, succinate and acetate 267(Holmes et al., 2007). Bacteroidetes also feature in coal (Li et al., 2008; Shimizu et al., 2007; 268Strapoć et al., 2008) and shale (Wuchter et al., 2013) microbial assemblages, although 269belonging to undescribed orders and families.

270

\subsection{Firmicutes}

272Within the phylum Firmicutes, Clostridia of the family Clostridiaceae include pH-neutral 273solvent producers, mixed acid and alcohol producers, and homoacetogenic fermenters 274(Wiegel et al., 2006). Species like Clostridium have been isolated from coal sources. For 275example Clostridium BC1 (Francis and Dodge, 1988), isolated from coal-cleaning residues, 276presented the ability to reduce heavy metals and fix nitrogen; Clostridium scatologenes is an 277acetogenic bacteria found in a coal mine (Küsel et al., 2000). In general, Clostridiaceae are 278widespread spore-forming, anaerobic bacteria that catalyse a wide range of metabolic 279reactions. Clostridia are known to depolymerize starch, chitin, xylan, and cellulose and are 280known to occur in sediments (Wiegel et al., 2006). Similarly, the Thermoanaerobacterales 281include thermophilic, anaerobic, fermentative bacteria that utilize a variety of carbon 282substrates and may have an important role in hydrocarbon-bearing formations (Wiegel et al., 2832006). The role of Firmicutes in coal activation has been observed before (Jones et al., 2008; 284Shimizu et al., 2007; Strapoć et al., 2008; Wawrik et al., 2012). Sporomusa, for example, can 285demethylate aromatic compounds; Acidoaminococcus sp. can ferment simple amino acids as 286a sole energy source. These microorganisms may potentially participate in the recycling of 287microbial biomass in unconventional gas systems. Although members of the Firmicutes often 
288represent a minor component of the community structure in CBM basins (Ritter et al., 2015), 289they play an important role in laboratory experiments (Barnhart et al., 2013; Green et al., 2902008; Jones et al., 2010; Li et al., 2008; Meslé et al., 2013; Penner et al., 2010). In microcosm 291experiments the addition of methanol stimulated Firmicutes growth compared with 292experiments with no carbonaceous nutrients (Wuchter et al., 2013), suggesting a role of this 293family in the syntrophic metabolism.

294

\subsection{Proteobacteria}

296The phylum Proteobacteria constitutes at present the largest and phenotypically most diverse 297phylogenetic lineage (Kersters et al., 2006). Syntrophic Beta, Delta and 298Gammaproteobacteria are commonly found in CBM (Guo et al., 2012a; Meslé et al., 2013; 299Penner et al., 2010; Robbins et al., 2016), but also in SG flowback water (Mohan et al., 3002013). Betaproteobacteria consist of several groups of aerobic or facultative bacteria that are 301highly versatile in their degradation capacities and often containing chemolithotrophic 302genera. Deltaproteobacteria include a branch of strictly anaerobic genera, which contains 303most of the known sulfate-reducing bacteria (SRB) (Desulfovibrio, Desulfobacter, 304Desulfococcus, Desulfonema, etc) and sulfur-reducing bacteria (e.g. Desulfuromonas spp.). 305Deltaproteobacteria includes SRB which are able to degrade naphthalene or other aromatic 306hydrocarbons (Musat and Widdel, 2008). Propane and butane degraders within the SRB were 307also detected in marine hydrocarbon cold seeps (Jaekel et al., 2013). Geobacter species are 308known to syntrophically degrade aromatics (Lovley and Lonergan, 1990; Rooney-varga et al., 3091999) and long-chain fatty acids (Coates et al., 1995) coupled to reduction of Fe(III) as a 310terminal electron acceptor. Geobacter metallireducens, for example, is genetically similar to 311Syntrophus, which can degrade a wide range of organics with a methanogenic partner 
312(McInerney et al., 2007). In the Bowen basin pumped coal mine waters from the subsurface 313were dominated by bacteria belonging to the family Rhodocyclaceae (Raudsepp et al., 2016). 314Gammaproteobacteria is a very large heterogeneous class; some denitrifying toluene315degrading strains belong to the Gammaproteobacteria and are able to degrade hydrocarbons 316with nitrate as electron acceptor (Alain et al., 2012). Although the majority of 317Gammaproteobacteria are chemoorganotrophs, this group also includes several 318chemolithotrophs that derive their energy via hydrogen-, sulfur- or iron- oxidation (Gao et al., 3192009; Kersters et al., 2006).

320

\subsection{Archaea}

322The archaeal diversity in SG and CBM is mostly restricted to methanogens from three orders: 323Methanosarcinales, Methanomicrobiales and Methanobacteriales (Green et al., 2008; Penner 324et al., 2010; Strapoć et al., 2011b). Within Methanosarcinales there are metabolically diverse 325methanogens capable of utilizing $\mathrm{H}_{2}-\mathrm{CO}_{2}$, acetate, and methyl compounds as substrates for 326methanogenesis (Whitman et al., 2006). In the San Juan Basin, sequence libraries analysis 327highlighted the presence of two families: Methanosaeta (obligate acetate utilizers) and 328Methanosarcina (metabolically versatile) (Wawrik et al., 2012). Methanosarcinales accounted 329 for the majority of the methanogens in coal samples from an abandoned mine in Germany 330(Beckmann et al., 2011) and also predominate in a consortium enriched from a CBM well 331from the Powder River Basin (Green et al., 2008). Cultivated strains of these taxa can utilize 332methyl compounds, including methanol and methylamines, where Methanolobus is not 333known to utilize acetate or $\mathrm{H}_{2}-\mathrm{CO}_{2}$. All species within the order Methanomicrobiales are 334known to utilize $\mathrm{H}_{2}-\mathrm{CO}_{2}$ to generate $\mathrm{CH}_{4}$, while none are capable of utilizing acetate (Garcia 335et al., 2006). The presence of Methanosarcina in numerous worldwide CBM may suggest 336acetoclastic methanogenesis but also intermittent oxygen intrusion in the formation (Ritter et 
337al., 2015), since Methanosarcina can survive to short oxygen exposure when in mixed 338cultures. In the Antrim Shale, the main methanogenic pathway is hydrogenotrophic, as 339discovered by Martini et al., (1996) and later confirmed by Waldron et al., (2007). In the 340same study, Martini et al., (1996) found that gases from a deeper producing well of the 341Antrim Shale, are thermogenic, suggesting that microbial gas could be limited to shallow 342formations.

343

3444. Methanogenic pathways

345

346The range of substrates that methanogens can utilise is limited (Table 1). Biogenic $\mathrm{CH}_{4}$ is 347primarily produced via $\mathrm{CO}_{2}$-reduction (Eq. 1) and acetate fermentation (Eq. 2). In the first 348pathway $\mathrm{H}_{2}$ is used as the electron donor and $\mathrm{CO}_{2}$ as the electron acceptor (Weimer and 349Zeikus, 1978); in the second acetate and hydrogen are used to produce $\mathrm{CH}_{4}$ and carbon 350dioxide (Conrad et al., 1989).

351

352(1)

$\mathrm{CO}_{2}+4 \mathrm{H}_{2} \rightarrow \mathrm{CH}_{4}+2 \mathrm{H}_{2} \mathrm{O}$

$353(2)$

$\mathrm{CH}_{3} \mathrm{COOH} \rightarrow \mathrm{CH}_{4}+\mathrm{CO}_{2}$

354

355The first and second pathways are called respectively hydrogenotrophic and acetoclastic 356methanogenesis. Methanogens can also use other substrates, such as methanol (Eq. 3) 357(Deppenmeier et al., 1999) and formate (Eq. 4) (Whiticar, 1999).

358

359(3)

$4 \mathrm{CH}_{3} \mathrm{OH} \rightarrow 3 \mathrm{CH}_{4}+\mathrm{CO}_{2}+2 \mathrm{H}_{2} \mathrm{O}$

$360(4)$

$4 \mathrm{HCOOH} \rightarrow 3 \mathrm{CO}_{2}+\mathrm{CH}_{4}+2 \mathrm{H}_{2} \mathrm{O}$ 
362The possible relevance for $\mathrm{CH}_{4}$ production of other substrates such as methylamines, 363dimethyl sulfide, ethanol, and isopropanol is not well documented; however, methylotrophic 364methanogens have been detected in coal, sandstone, produced water samples (Guo et al., 3652012b) and shales (Waldron et al., 2007). These substrates might be the important compounds 366for the enhancement of biogenic $\mathrm{CH}_{4}$ generation in sedimentary rocks. In particular, 367methylamines and dimethyl sulfide are considered non-competitive substrates: when 368sufficient concentration of methylamines and dimethyl sulfide are present, methanogenesis 369and sulfate reduction are not mutually exclusive (Mitterer, 2010). For the conversion of more 370complicated organic substrates to $\mathrm{CH}_{4}$, other microorganisms such as acetogenic and 371fermentative bacteria are also present.

372

373Table 1. Substrates of major taxonomic groups of methanogens

\begin{tabular}{lll}
\hline Order & Family & Substrates \\
\hline Methanobacteriales & Methanobacteriaceae & $\mathrm{H}_{2}-\mathrm{CO}_{2}$, formate, methanol \\
\cline { 2 - 3 } & Methanothermaceae & $\mathrm{H}_{2}-\mathrm{CO}_{2}$ \\
\hline Methanococcales & Methanococcaceae & $\mathrm{H}_{2}-\mathrm{CO}_{2}$, formate \\
\cline { 2 - 3 } & Methanocaldococcaceae & $\mathrm{H}_{2}-\mathrm{CO}_{2}$ \\
\hline Methanomicrobiales & Methanomicrobiaceae & $\mathrm{H}_{2}-\mathrm{CO}_{2}$, formate \\
\cline { 2 - 3 } & Methanospirillaceae & $\mathrm{H}_{2}-\mathrm{CO}_{2}$, formate \\
\cline { 2 - 3 } & Methanocorpuscolaceae & $\mathrm{H}_{2}-\mathrm{CO}_{2}$, formate \\
\hline Methanosarcinales & Methanosarcinaceae & $\mathrm{H}_{2}-\mathrm{CO}_{2}$, methylamine, \\
\cline { 2 - 3 } & Methanosaetaceae & acetate \\
\hline Methanopyrales & Methanopyraceae & $\mathrm{H}_{2}-\mathrm{CO}_{2}$ \\
\hline
\end{tabular}

374

\subsection{Isogeochemical indicators of biogenic $\mathrm{CH}_{4}$ in $S G$ and $C B M$}

376Several studies on methanogenic environments in sedimentary basins world-wide have 377developed a set of geochemical and isotopic indicators for biogenic $\mathrm{CH}_{4}$ in organic-rich rocks 378(Whiticar, 1999; Straapoć et al., 2007; McIntosh et al., 2008; Osborn et al., 2010; Golding et 379al., 2013). Dual plot of carbon $\left({ }^{13} \mathrm{C} /{ }^{12} \mathrm{C}\right)$ and hydrogen $(\mathrm{D} / \mathrm{H})$ isotope ratios of $\mathrm{CH}_{4}$ are applied 
380for distinguishing microbial from thermogenic $\mathrm{CH}_{4}$ in the environment (Fig. 3) (Strapoć et al., 3812011; Whiticar, 1990), as well as for apportioning pathways of biogenic $\mathrm{CH}_{4}$ production 382(Burke et al., 1988). The ratios, expressed in $\delta$ notation, are in units per mille (\%o), relative to 383the isotopic composition of the internationally agreed standards VPDB (Vienna Pee Dee 384Belemnite) and VSMOW (Vienna Standard Mean Ocean Water) respectively for carbon and 385hydrogen isotopes. Biogenic $\mathrm{CH}_{4}$ has a wide range of $\delta^{13} \mathrm{C}$ (from -110 to $-50 \%$ ) and $\delta \mathrm{D}$ (from 386-400 to -150\%) (Whiticar and Faber, 1986). The $\delta^{13} \mathrm{C}$ value of $\mathrm{CH}_{4}$ is commonly coupled with 387other isotopic indicator in order to distinguish between microbial and thermogenic $\mathrm{CH}_{4}$, since $388 \delta^{13} \mathrm{C}$ values of biogenic $\mathrm{CH}_{4}$ are sometimes similar to those of thermogenic $\mathrm{CH}_{4}$ (Coleman et al., 1988; 389 Jenden et al., 1988; Schoell, 1980; whiticar and Faber, 1986). The hydrogen isotope signature of $\mathrm{CH}_{4}$ distinguishes 390between gas origins and can identify secondary processes such as migration or mixing 391(Martini et al., 1998). The hydrogen isotope signature of $\mathrm{H}_{2} \mathrm{O}$ and $\mathrm{CH}_{4}$ also provides a 392powerful analytical tool to distinguish methanogenic pathways independently of the carbon 393isotope signature (Schoell, 1980; Whiticar and Faber, 1986). Despite the significance of dual 394carbon and hydrogen isotope signatures, different origins of $\mathrm{CH}_{4}$ often yield overlapping 395characteristic isotope signals (Pohlman et al., 2009; Whiticar, 1999, 1990). The empirical396based interpretations of multidimensional isotope signatures should be used with caution and 397coupled with other available microbiological and geochemical data (Strapoć et al., 2011). For 398example, carbon isotopic differences between $\mathrm{CH}_{4}$ and $\mathrm{CO}_{2}\left(\delta^{13} \mathrm{C}_{\mathrm{CO}}\right.$ - $\left.{ }_{\mathrm{CH}}\right)$ can be helpful to 399understand gas origin (Strąpoć et al., 2011b): thermogenic process are characterized by low $400 \delta^{13} \mathrm{C}_{\mathrm{CO} 2-\mathrm{CH} 4}$ determined by high temperatures; conversely, low-temperature microbial 401enzymatic process determine a ${ }^{13} \mathrm{C}$ enrichment in residual $\mathrm{CO}_{2}$ (Conrad and Klose, 2005). In 402mixtures of thermogenic and biogenic gases, $\delta^{13} \mathrm{C}_{\mathrm{CO} 2}$-СH4 can be more suitable than the 403absolute value of $\delta^{13} \mathrm{C}$ for discriminating gas origin (Smith and Pallasser, 1996; Strapoć et al., 4042007). Three diagnostic geochemical variables were identified by Martini et al., (2008): (i) 
405alkalinity and $\delta^{13} \mathrm{C}$ of dissolved inorganic carbon (DIC) in the coproduced water, (ii) $\delta^{2} \mathrm{H}$ of 406 $\mathrm{CH}_{4}$ and coproduced water and (iii) $\delta^{13} \mathrm{C}$ of $\mathrm{CO}_{2}$. Other common indicators, such as the $\delta^{13} \mathrm{C}$ 407of $\mathrm{CH}_{4}$ and the ratio of $\mathrm{C} 1 /[\mathrm{C} 2+\mathrm{C} 3]$, have proven to be unreliable in unconventional basins 408where a host of secondary effects occurs and the biogenic $\mathrm{CH}_{4}$ generated commonly has high $409 \delta^{13} \mathrm{C}$ values (approximately -48\%) which overlap with early thermogenic $\mathrm{CH}_{4}$ values (Martini 410et al., 2003; Whiticar, 1999). Isotopic and geochemical indicators of biogenic $\mathrm{CH}_{4}$ production 411have been proved to be more effective when accompanied by molecular/microbial methods 412(Raudsepp et al., 2015). For example, isotopic studies indicated that in the Wilcox Group 413CMB, $\mathrm{CO}_{2}$ reduction was the dominant pathways of $\mathrm{CH}_{4}$ production (McIntosh et al., 2010; 414Warwick et al., 2008), but microbiological data pointed out that methylotrophic methanogens 415(Doerfert et al., 2009) or acetoclastic methanogens (Jones et al., 2010) were likely to be the 416main pathways of $\mathrm{CH}_{4}$ generation. In the Powder River Basin, isotopic data of $\mathrm{CH}_{4}$ indicated 417that hydrogenotrophic methanogenesis was the dominant pathway (Flores et al., 2008; Rice et 418al., 2008), while microbial enrichments from the same area of the basin have shown a 419predominance of acetoclastic methanogens (Green et al., 2008). The different conclusions of 420these studies indicate that the microbial communities enriched in laboratory may not be 421representative of the dominant microbial populations in situ. The relationship between carbon 422isotope signature of $\mathrm{CH}_{4}$ and $\mathrm{CO}_{2}\left(\delta^{13} \mathrm{C}_{\left.\mathrm{CO}_{2}-\mathrm{CH}_{4}\right)}\right.$ could be a better indicator of the extent of 423methanogenesis than the methanogenic pathway (Brown, 2011; Hamilton et al., 2015, 2014; 424Strapoc et al., 2007). The typical $\delta^{13} \mathrm{C}_{\mathrm{CO} 2}-\mathrm{CH}_{4}$ range for microbial $\mathrm{CO}_{2}$-reduction to methane 425is of $60-80 \%$ (Smith and Pallasser, 1996). This carbon isotopic difference arises from 426preferential microbial utilization of ${ }^{12} \mathrm{CO}_{2}$. As a result, residual $\mathrm{CO}_{2}$ becomes ${ }^{13} \mathrm{C}$-enriched 427(average $\delta^{13} \mathrm{C}_{\mathrm{CO} 2}$ of about 4.3\%) and thus contrasts sharply against $\mathrm{CO}_{2}$ in thermogenic gases 428with $\delta^{13} \mathrm{C}$ values of around 20\% (Smith and Pallasser, 1996). 


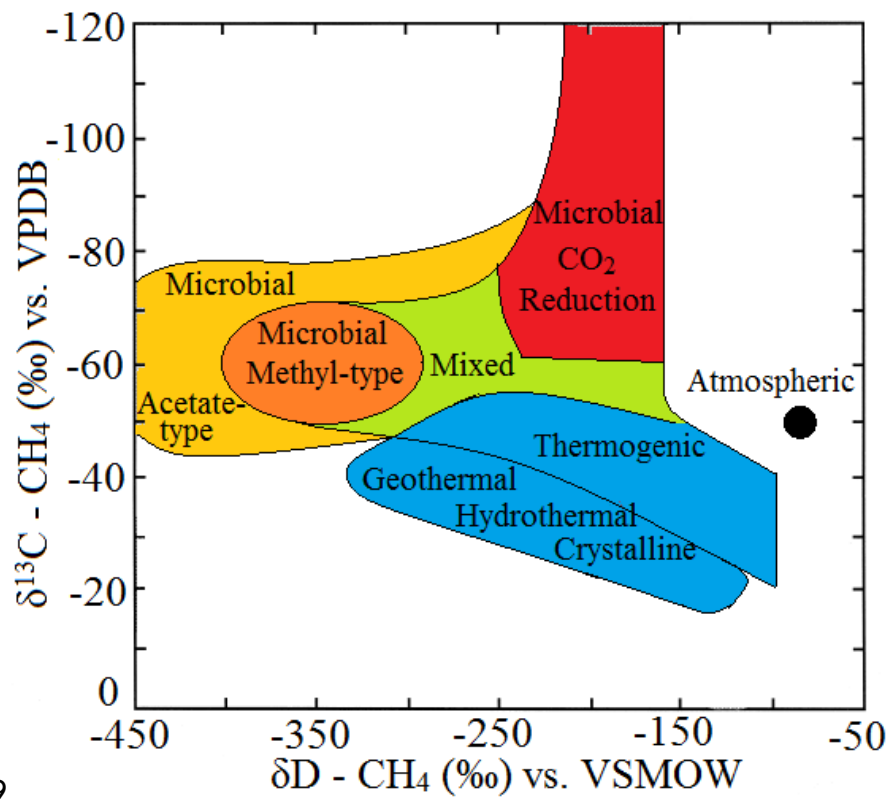

429

430Fig. 3. Dual plot of $\delta^{13} \mathrm{C}$ and $\delta \mathrm{D}$ of $\mathrm{CH}_{4}$ for the classification of 431microbial and thermogenic $\mathrm{CH}_{4}$. Adapted from Whiticar (1986).

432

4335. Microbial processes in unconventional gas basins

434

435The pattern of anaerobic mineralisation of OM involves the activation of complex 436macromolecular compounds, such as aliphatics, aromatics and heteroatoms by primary 437fermenting bacteria. Then secondary fermenters degrade less complex compounds to a 438variety of fatty acids, $\mathrm{CO}_{2}$ and $\mathrm{H}_{2}$. Acetogenic bacteria degrade (higher) fatty acids to acetate, 439formate, $\mathrm{CO}_{2}$ and $\mathrm{H}_{2}$, that can be used by methanogens. Acetate can also be degraded into $\mathrm{H}_{2}$ 440and $\mathrm{CO}_{2}$ via syntrophic acetate oxidation, as observed in the Yabase oil field in Japan 441(Mayumi et al., 2011). These processes take place simultaneously, but because of the different 442growth rates and activities of the microorganisms involved, the processes are partially 443uncoupled, resulting in the accumulation of organic acids (Stams et al., 2012). 444Methanogenesis is in fact a dynamic process and strongly influence the metabolism of 445fermentative and acetogenic bacteria by means of interspecies $\mathrm{H}_{2}$ transfer (Schink and Stams, 4462006; Stams and Plugge, 2009). Hydrogen syntrophy is hypothesised to be also responsible 
447for anaerobic oxidation of $\mathrm{CH}_{4}$ (Reeburgh and Heggie, 1977). In organic-rich and anaerobic sediments, 448SRB play a role in the anaerobic oxidation of $\mathrm{CH}_{4}$ (Eq. 5) (Zehnder and Brock, 1979) through 449a process called reverse methanogenesis.

450

$$
\mathrm{CH}_{4}+\mathrm{SO}_{4}{ }^{2-} \rightarrow \mathrm{HCO}_{3}^{-}+\mathrm{HS}^{-}+\mathrm{H}_{2} \mathrm{O}
$$

452

453Anaerobic oxidation of $\mathrm{CH}_{4}$ coupled to sulfate reduction is assumed to be a syntrophic 454process, where $\mathrm{H}_{2}$ syntrophy is the basis of the methanogen/SRB consortium (Valentine and 455Reeburgh, 2000). $\mathrm{H}_{2}$ concentration is indicative of the dominant terminal electron-accepting 456process (Lovley and Phillips, 1987; Lovley and Goodwin, 1988; Hoehler et al., 1998). The 457maintenance of low $\mathrm{H}_{2}$ allows the syntrophic oxidation of organic material through 458interspecies $\mathrm{H}_{2}$ transfer (Schink, 1997; Wolin, 1982). Under sufficiently low $\mathrm{H}_{2}$, methanogens 459reverse their metabolism and mediate the reversal of methanogenesis, using water as the 460terminal electron acceptor. The $\mathrm{H}_{2}$ is removed and maintained at low concentrations by SRB 461in syntrophic association with methanogens (Hoehler and Alperin, 1996). SRB are more 462efficient at using $\mathrm{H}_{2}$ as an electron donor; thus, they can create conditions that 463thermodynamically favour the oxidation of $\mathrm{CH}_{4}$.

464Being rich in organic carbon, shale and coal could be considered a suitable substrate for 465microbial activity, although kerogen is a complex and biologically recalcitrant material, 466composed of a mix of aliphatics (Orem et al., 2010), aromatic hydrocarbons (Orem et al., 4672010, 2007; Ulrich and Bower, 2008) and heteroatoms (Orem et al., 2007). Microorganisms 468interact with $\mathrm{OM}$ in different ways, including biological depyritization, solubilisation by 469biologically produced alkaline materials and by biological chelators (Polman et al., 1994). 470The biodegrading capabilities of anaerobic bacteria were discovered in relatively recent time, 471as compared with aerobic-degraders (Widdel and Grundmann, 2010). The electron acceptors 
472most frequently studied and used by anaerobic microorganism during biodegradation are 473nitrate and sulfate, although anaerobic degradation of hydrocarbons has been observed with 474Fe(III), Mn(IV) reduction (Lovley, 1991), and under methanogenic conditions via syntrophic 475interspecies electron transfer (Mbadinga et al., 2011).

476However, the OM buried in sediments is a complex mixture of geopolymers and the types of 477organic compounds that can be oxidized to $\mathrm{CO}_{2}$ and $\mathrm{CH}_{4}$ are related to the different terminal 478electron acceptors (Fig.4).

479

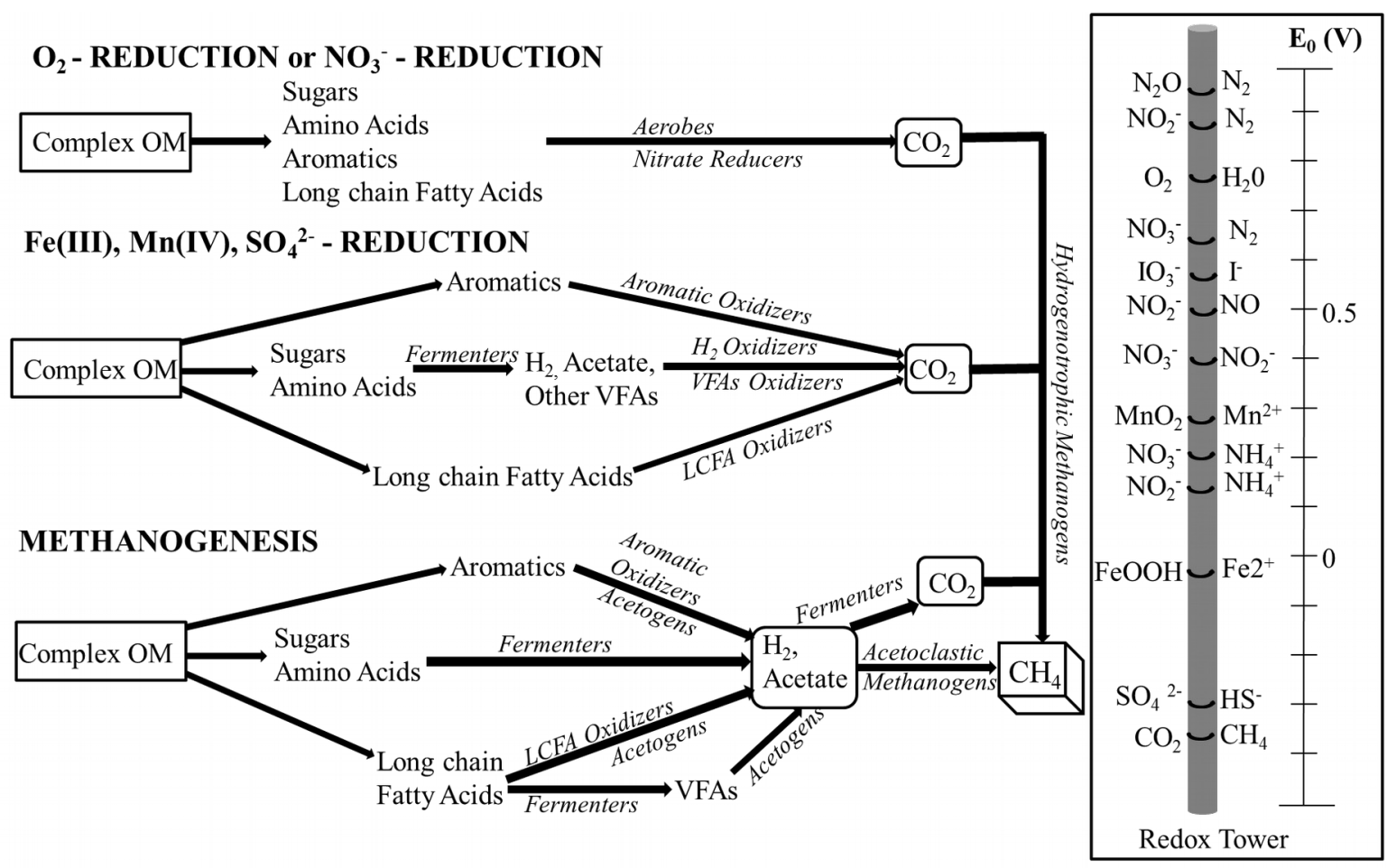

480

481Fig. 4. Schematic of putative microbial processes in subsurface environments. The figure shows the main 482reactions and groups of microorganisms involved in $\mathrm{CH}_{4}$ production, highlighting the formation of 483methanogenic intermediate of biodegradation. Modified from (Lovley and Chapelle, 1995). The insert on the 484right is the redox tower, showing the reduction potential $\left(\mathrm{E}_{0}\right)$ of the microbial processes.

485

486Few researchers have aimed to detect the degradation pathways of OM in CBM (Formolo et 487al., 2008; Jones et al., 2010, 2008Warwick et al., 2008). Yet, the biodegradation pathways and 488the intricate microbial relationships required to convert complex $\mathrm{OM}$ to $\mathrm{CH}_{4}$ are not well 
489understood, as acknowledged by Gieg et al., (2010); Jones et al., (2010, 2008); McInerney et 490al., (2009); Orem et al., (2010); Ritter et al., (2015); Strapoć et al., (2008). A number of 491studies for bioremediation have investigated the mechanisms by which anaerobic 492microorganisms activate and degrade complex hydrocarbon compounds. The anaerobic 493degradation of OM in shale and coal however, is expected to follow different pathways than 494the most studied biodegradation for bioremediation purposes. The vast body of scientific 495knowledge on contaminated land bioremediation can help to shed light on the complex 496degradation pathways of $\mathrm{OM}$ in unconventional gas systems. A schematic representation of 497the anaerobic degradation of OM from shale and coal is illustrated in Figure 3, highlighting 498putative activation sites of OM, and showing the general pathways of anaerobic 499biodegradation of aliphatic, aromatic and heteroatom hydrocarbons.

500

\subsection{Aliphatics}

502The anaerobic activation of alkanes is of particular interest since they are unreactive 503compounds containing only apolar $\sigma$-bonds: the most common activation is the hydrocarbon 504addition to fumarate, yielding alkylsuccinates (Widdel and Grundmann, 2010). The 505biodegradation of aliphatic and cyclic hydrocarbons can be a source of metabolites (fatty 506acids) that can be further oxidised to methanogenic substrates (Warwick et al., 2008); the 507biochemistry and subsequent degradation of alkylsuccinates is also expected to lead to fatty 508acid metabolism (Widdel and Rabus, 2001). Although fatty acids are a feedstock for 509methanogens, the accumulation of such compounds could potentially cause inhibition of 510methanogenesis, due to lowering of pH, (Jones et al., 2010). Alkenes activation occurs mostly 511from the hydration of the double bond. The biodegradation of monoterpenes and other 512isoprenoids in anaerobic ecosystems was observed under denitrifying conditions (Harder, 5132000; Hylemon and Harder, 1998). 


\subsection{Aromatics}

516The biodegradation of aromatic compounds has been long studied, since the presence of such 517“contaminants” in many aquifers all around the world. These compounds are often toxic and 518their aqueous solubility is also an issue. The simple alkyl-substituted aromatic hydrocarbons 519are more readily degraded under anaerobic conditions than unsubstituted aromatics. For 520example, the degradation of toluene under methanogenic conditions require the activity of the 521benzylsuccinate synthase, which catalyses the addition of the methyl carbon of toluene to the 522double bond of fumarate (Beller and Edwards, 2000). Ethylbenzene can be completely 523oxidised to $\mathrm{CO}_{2}$ by an ethylbenzene-oxidising bacterium (Strain EB1) under denitrifying 524conditions but not under oxic conditions (Ball et al., 1996). The final biodegradation products 525of ethylbenzene are potential substrates for hydrogenotrophic methanogens. The 526biodegradation of benzoate by a pure culture of Syntrophusaciditrophicus produced 1.5 mol 527of acetate per mol of benzoate in absence of $\mathrm{H}_{2}$-utilizing partners or terminal electron 528acceptors: in co-cultures with Methanospirillum hungatei it produced $3 \mathrm{~mol}$ of acetate and $5290.75 \mathrm{~mol}$ of $\mathrm{CH}_{4}$ per mol of benzoate (Elshahed and McInerney, 2001). Sporomaculatum 530hydroxybenzoicum biodegraded 3-hydroxybenzoate in the absence of hydrogenotrophic 531microorganisms by using the crotonyl coenzyme A, which results in the final production of 532butyrate, acetate and $\mathrm{HCO}_{3}{ }^{-}$(Müller and Schink, 2000). The results of these studies may be 533significant to elucidate the degradation pathways of aromatic compounds in OM. Benzoate is 534a central intermediate in anaerobic degradation of many natural and xenobiotic aromatic 535compounds (Elshahed and McInerney, 2001). Biodegradation studies with unsubstituted 536aromatic hydrocarbons were carried out mostly with benzene and naphthalene under sulfate537reducing conditions: for the activation of these compounds, the mechanisms include the 538addition of $\mathrm{CO}_{2}$-derived carboxyl group (Annweiler et al., 2002; Widdel and Rabus, 2001). 
539Recent studies investigated the carboxylation of benzene and naphthalene via the putative 540enzymes benzene carboxylase (Abu Laban et al., 2009) and naphthalene carboxylase 541(Bergmann et al., 2011). Polycyclic aromatic hydrocarbons (PAHs) are commonly found in 542coal formation waters, coal extractable OM and methanogenic coal incubations (Strapoć et 543al., 2011). Many prokaryotes are capable of mineralising PAHs under anaerobic conditions; 544the degradation rates are usually fastest under sulfidogenic conditions, followed by 545methanogenic and finally nitrate-reducing conditions (Chang et al., 2002). A common 546bacterial strategy, which influences the PAH degradation, is the release of biosurfactants, 547small detergent-like molecules with a hydrophilic head and a lipophilic tail. Hydrophobic 548compounds become solubilized in the hydrophobic cores of the micelles, which leads to a 549transfer of PAHs from solid, liquid, or sorbed PAHs into the water phase (Johnsen et al., 5502005). Although in the absence of nitrate or sulfate the anaerobic biodegradation of PAHs is 551thermodynamically unfavourable, in the presence of active methanogenic bacterial species 552these complex compounds may be degraded by the syntrophic food chain. The initial steps 553could involve the degradation of organic compound to $\mathrm{H}_{2}$ and $\mathrm{CO}_{2}$ : subsequent utilisation of $554 \mathrm{H}_{2}$ by methanogens, reducing $\mathrm{CO}_{2}$ to $\mathrm{CH}_{4}$, provides enough energy to make the overall 555reaction thermodynamically favourable (Genthner et al., 1997); thus, methanogenic bacteria 556serve as terminal electron sink via interspecies hydrogen transfer, and make biodegradation of 557PAHs thermodynamically feasible (McInerney and Bryant, 1981). The capability for 558anaerobic hydrocarbon degradation appears to be rather widespread in various lines of 559phylogenetic descent. The diversity of anaerobic hydrocarbon degraders may indicate that 560hydrocarbons were already used as growth substrates at an early stage of bacterial evolution 561and the anaerobic metabolism may be older than the aerobic (Widdel and Rabus, 2001). 562Altogether the pathways for the biodegradation of organic compounds can be summarized in 563reactions of fumarate addition, hydroxylation, C1 addition/carboxylation, and methylation 
564(Strapoć et al., 2011). The anaerobic degradation of organic compounds is less documented as 565compared with the aerobic biodegradation, and most of these pathways are not completely 566understood. Many data, however, are available from studies of bioremediation in anoxic soil, 567and may help to decipher the complicated pathways of biodegradation of geologically-old $568 \mathrm{OM}$ and the microbial consortia involved in the syntrophic chain. The relevance of these 569studies is not only related to the planning of in-situ stimulation strategies, but also to 570remediate or mitigate accidental contamination due to drilling activities, mining and storage 571of wastewater.

572

\subsection{Heteroatoms}

574NSO (nitrogen-, sulfur- and oxygen-containing heterocyclic compounds) were found in coal 575(Orem et al., 2007; Wawrik et al., 2012) and shale formations (Gross et al., 2015). 576Heteroatoms were long considered recalcitrant to biodegradation, and in a "susceptibility 577scale” classified as the last group of compounds, after normal alkanes (usually catabolized 578first), followed by branched alkanes, monocyclic saturated, monoaromatic hydrocarbons and 579PAHs (Hunt et al., 1995; Rowland et al., 1986; Volkman et al., 1983; Wenger and Isaksen, 5802002). NSO compounds are not as recalcitrant as once believed and could undergo selective 581degradation process as complex as those for hydrocarbons (Kim et al., 2005) NSO 582compounds are more soluble in water than PAHs, since the replacement of a carbon atom 583with a nitrogen, sulfur or oxygen atom result in higher polarity and hence higher water 584solubility and increased bioavailability and mobility. Also, chemical bonds between carbon 585and heteroatoms have lower bond dissociation energies than aliphatic or aromatic C-C bonds 586(Savage, 2000). Thus, heteroatoms are more reactive than PAHs, characterised by C-C bonds; 587the mechanisms of activation of these compounds are similar to biodegradation pathways 
588observed for PAHs, and could include demethoxylation as demonstrated by stable isotope 589probing (Liu and Suflita, 1993).

590

a

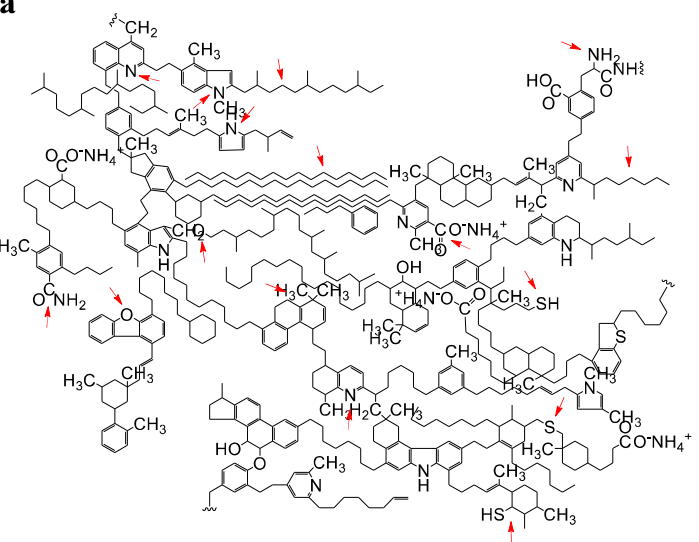

b

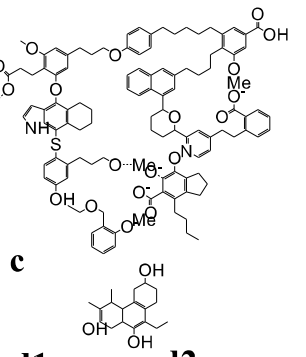

d1

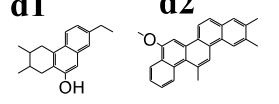

e

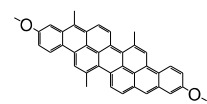

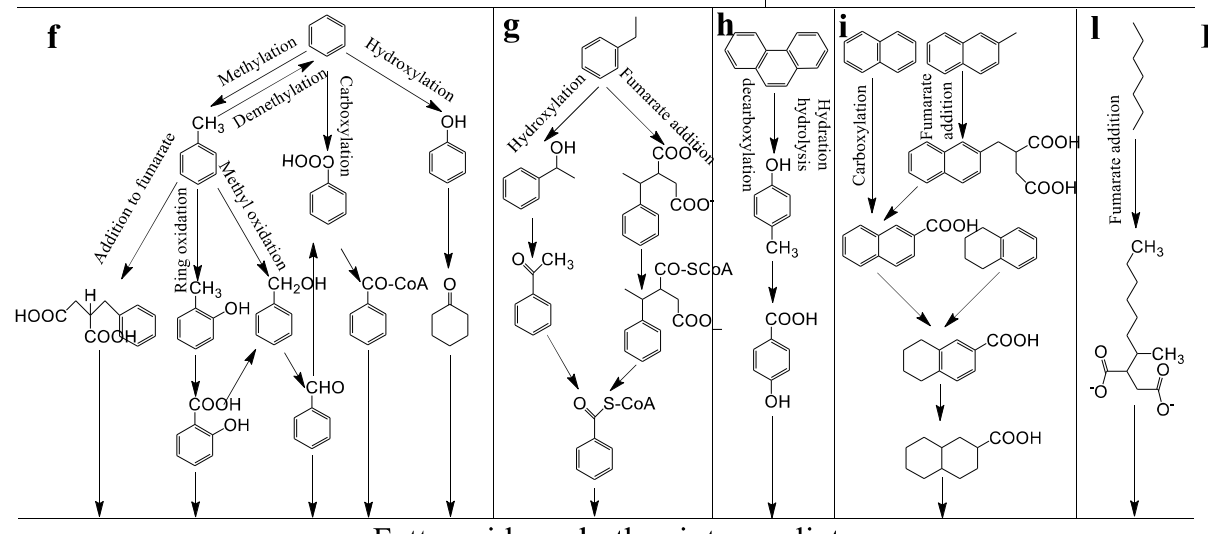

Fatty acids and other intermediates

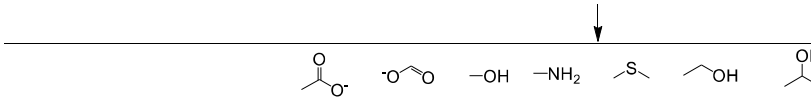

591

Complex organic matter Exoenzymatic hydrolysis, fragmentation, activation and dissolution

Long chain aliphatics, aromatics, heteroatoms Activation, fermentation and oxidation<smiles>[3H][13CH3]</smiles>

Soluble organic molecules, Acetogenesis, $\mathrm{H}_{2}$ production, and release of methanogenic substrates

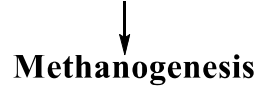

592Fig. 2. General biodegradation pathways of OM from shale and coal. Schematic representation of the 593microbial anaerobic biodegradation of OM. Red arrows indicate the putative activation sites for the microbial 594transformation of OM (from Strapoć et al., (2011). (a) Structural model of the oil shale kerogen (Green River), 595redraw from Vandenbroucke and Largeau, (2007). (b, c, d1, d2, e) Typical structures of different ranks of coal, 596modified from Fakoussa and Hofrichter, (1999). (f) Schematic biodegradation of benzene, toluene and phenol, 597modified from Grbić-Galić and Vogel, (1987), using McInerney et al., (2009) for benzoate degradation. (g) 598Representation of ethylbenzene biodegradation, redrawn from Kniemeyer and Heider, (2001), (h) anaerobic 599biotransformation of phenanthrene, redrawn from Haritash and Kaushik, (2009). (i) Naphthalene 
600biodegradation, redrawn from Annweiler et al., (2002). (l) Short schematic degradation of heptane adapted from 601Strąpoć et al., (2011).

602

6036. Environmental requirements for in situ biogenic $\mathrm{CH}_{4}$ production

604

605Biogenic $\mathrm{CH}_{4}$ production is significant in nearly every shallow coal seam at temperatures less 606than $80^{\circ} \mathrm{C}$ (Jin et al., 2010; Pfeiffer and Ulrich, 2010), in SG basins the contribution of 607biogenic $\mathrm{CH}_{4}$ is also depth related in the majority of basins (Golding et al., 2013; Krumholz et 608al., 1997; Martini et al., 2008; McIntosh et al., 2008). The relationship between 609methanogenesis and depth is not controlled only by temperature, but also correlates with 610possible events of natural groundwater recharge that enhances methanogenesis by either (i) 611transporting microorganisms into organic-rich reservoirs, providing moisture necessary for 612microbial activity, decreasing salinity, removing waste products, and/or (ii) transporting 613nutrients necessary for microbial growth (Jones et al., 2013; Martini et al., 1996; McIntosh et 614al., 2002; Strpoć et al., 2010, 2008; Zhang et al., 2013). Reduction in $\mathrm{Cl}^{-}$concentration is 615crucial for promoting methanogenesis in basins with high salinities, since methanogens prefer 616salinity gradient between 0.5 and $4 \mathrm{M} \mathrm{Cl}^{-}$(Orem et al., 2010; Osborn and McIntosh, 2010; 617Schlegel et al., 2011b; Patricia J. Waldron et al., 2007; Zinder, 1993). The observation that 618microbial gas generation occurs at significant rates only in shallow CBM and shale gas basins 619is also dependant on the bioavailability of readily degradable OM. With increasing depth, the 620organic compounds become more recalcitrant to biodegradation (Head et al., 2003; Wellsbury 621et al., 1997; Strapoc et al., 2008; Robbins et al., 2016). Recent studies showed a significant 622negative correlation between final biogenic methane yield and rank, suggesting that the 623bioavailability of the coal organic material decreases with increasing thermal maturity 624(Robbins et al., 2016). The chemistry of coal changes systematically with increasing rank, as 625oils and gases are generated and then cracked, producing abiotic methane and higher 
626hydrocarbon gases, thus reducing the fraction of biodegradable moieties (Papendick et al., 6272011). The negative correlation between biogenic methane and rank of coal does not provide 628an exhaustive explanation of biogenic $\mathrm{CH}_{4}$ production, suggesting that other limiting factors 629such as the accessibility of microbes to OM could play a more important role. Although the 630transport/presence of bacteria in organic-rich rocks cannot be completely ruled out, 631indigenous microbial communities live mainly within fractures (cleats) in shale and coal 632formations, or at the interface of coal with overlying or underlying rock layers (Fredrickson 633et al., 1997; Martini et al., 1998; Scott, 1999). This provides limited surface area for the 634microorganisms to interact with OM. It has been suggested that the pore throat size must be 635double the diameter of cells to allow bacteria to effectively pass through (Fredrickson et al., 6361997). In the Illinois Basin CBM, Strapoć et al., (2008) reported that the dominant 637methanogen was on average $0.4 \mu \mathrm{m}$ in diameter, indicating that pores and/or fractures in 638reservoirs supporting methanogenesis must be much greater in diameter. In sandstone 639formations with permeability less than $100 \mathrm{mD}$, the bacterial penetration typically occur 640slowly (Jenneman et al., 1985), suggesting that in shale-sandstone sequence, microorganisms 641are slowly, but steadily transported in the deep subsurface. Competition with other groups of 642microorganisms could be another limiting factor, several studies have investigated the 643competition between SRB and methanogens. These studies suggested that methanogenesis 644and sulfate reduction are mutually exclusive due to competition for carbon substrates 645(Claypool and Kaplan, 1974; Kuivila et al., 1989; Lovley and Phillips, 1987; Mah et al., 6461977; Martens and Berner, 1974; Reeburgh and Heggk, 1977). In the absence of sulfate, SRB 647may play a role in the breakdown of OM into methanogenic substrates (Mah et al., 1977; 648Raskin et al., 1996; Wawrik et al., 2012). Depending on the redox conditions and availability 649of substrates, the two processes can take place simultaneously, although the sequential 650dominance of SRB or methanogens in a given interval is more likely to happen. The 
651dominance of a particular class of microorganisms is dependent on many factor, such as $\mathrm{H}_{2}$ 652concentration, which control also the production and oxidation of $\mathrm{CH}_{4}$ under anaerobic 653conditions.

654

6557. Stimulation of biogenic $\mathrm{CH}_{4}$ production

656

657Research into the stimulation of biogenic $\mathrm{CH}_{4}$ production in unconventional gas systems is a 658new focus area for engineers and scientists. There are some similarities with conventional 659microbial enhanced oil recovery, but many research questions remain unanswered. Recently, 660there has been considerable work on microbial methanogenesis in CBM (Green et al., 2008; 661Harris et al., 2008; Jones et al., 2010; Papendick et al., 2011; Penner et al., 2010; Ritter et al., 6622015; Singh et al., 2012) and SG (Martini et al., 1998; Jones et al., 2010), reflecting the 663potential for in situ sustainable regeneration of $\mathrm{CH}_{4}$. While microbial methanogenesis in 664unconventional formations is complicated by a number of biogeochemical factors, a review 665of the relevant microbiological and geochemical literature allows the identification of key 666parameters for in situ stimulation strategies that include:

667

6681 . presence of viable methanogens and primary/secondary fermenters

6692 . competition for methanogenic substrates;

670 3. methanogesis rates;

6714 . bioavailable/biodegradable OM;

672 5. temperature;

673 6. formation salinity;

6747. presence of fractures and pore size distribution.

675

676Strategies for the in situ stimulation of $\mathrm{CH}_{4}$ production typically include technologies 677developed for the bioremediation of contaminated sites, such as (i) the addition of inorganic 678or organic nutrients in order to stimulate the native microbial populations (biostimulation) 
679and (ii) the addition of a microbial consortium (bioaugmentation). Other consolidated 680technologies in the unconventional gas industry could potentially be used to achieve optimal 681conditions in the formation, including hydraulic fracturing that can (iii) increase the contact 682surface area of microorganisms to coal/shale and (iv) increase the bioavailability of OM. 683These approaches could be used separately or in combination to achieve a continuous 684generation of biogenic $\mathrm{CH}_{4}$ from existing producing wells or depleted wells.

685

\subsection{Biostimulation}

687Microbial stimulation involves the addition of nutrients and/or electron donors and acceptors 688to the formation in order to stimulate $\mathrm{CH}_{4}$ production from indigenous microorganisms. 689Nutrients are typically added in formations where biogenic $\mathrm{CH}_{4}$ generation is active or where 690methanogenic rates are decreasing over time in the attempt to stimulate the growth of 691methanogenic communities and shift redox conditions to methanogenesis (Barnhart et al., 6922013; Fallgren et al., 2013; Jones et al., 2010; Ritter et al., 2015). The addition of 693methanogenic substrates such as $\mathrm{CO}_{2}-\mathrm{H}_{2}$ or acetate could stimulate biogenic $\mathrm{CH}_{4}$ production, 694but the primary goal of microbial stimulation should be to target primary and secondary 695fermenters (Mahaffey et al., 2013; Schlegel et al., 2013) able to degrade the complex 696geopolymers and release intermediary products that can be converted to $\mathrm{CH}_{4}$ by methanogens. 697This should take into account that syntrophic and fermentative bacteria, which are likely to be 698the main contributor to OM breakdown, survive near the thermodynamic limits of life 699(Elshahed and McInerney, 2001; McInerney et al., 2008) and, therefore, their growth is slow 700(Lovley, 1991) and dependant on several other factors. The introduction of electron 701donors/acceptors, which could stimulate microbial growth, is likely to divert electrons away 702from methanogenesis, since stimulation of more rapid organic release could result in toxic 703conditions that could limit biogenic $\mathrm{CH}_{4}$ generation (Jones et al., 2008). Biostimulation seems 
704to be the primary approach of current commercial stimulation projects (Luca Technologies: 705Mahaffey et al., (2013); Next Fuel: Fallgren et al., (2013); Ciris: Ciris Energy, 2013).

706

\subsection{Bioaugmentation}

708Bioaugmentation involves the introduction of microorganisms into the target environment to 709increase the in situ metabolic activity (Silva and Alvarez, 2010). Bioaugmentation may 710consist of a single microorganism or more typically a consortium of microorganisms (i.e., 711Bacteria and Archaea). In most cases, the microorganisms to be injected do not originate from 712the target environment, but are enriched and evaluated for high methanogenesis rates in 713laboratory experiments. When introducing an enriched consortium in the target formation, 714 $\mathrm{CH}_{4}$ generation rates could be much lower than in laboratory studies, where incubations are 715typically carried out with small chips of rock, therefore the accessibility of the 716microorganisms to OM is greatly increased when compared with in-situ conditions. This 717could bring biases in the results, leading to an overestimation of the $\mathrm{CH}_{4}$ generation rates. 718Although the bioaugmentation method was shown to produce more $\mathrm{CH}_{4}$ than biostimulation 719(Jones et al., 2010), it may be difficult, in some cases, to obtain permission from regulatory 720agencies to inject microorganisms into the subsurface, especially in areas where adjacent 721aquifers are used for drinking water. Very few research groups have pursued the microbial 722augmentation approach at the field scale (Ritter et al., 2015). MicGas ${ }^{\mathrm{TM}}$, for example, used a 723combination of biostimulation and bioaugmentation, adapting methanogens derived from

724termites to coal in the presence of appropriate nutrients (see 725http://www.arctech.com/micgas.html).

726

7277.3. Increase the contact surface area of microorganisms to coal/shale 
728Since the pore matrix of coal and shale is typically too small for microorganisms, 729methanogenesis is often limited to fractures (Scott, 1999) and at the fringe between the 730source rock and more permeable formations, where the pore size is greater, as well as the 731availability of water (Krumholz et al., 2002; Martini et al., 1998). Increasing the surface area 732available for microbial colonization could be accomplished through existing techniques, such 733as hydraulic fracturing. Hydraulic fracturing is carried out to increase the permeability of SG 734formations and coal seams, and involves the pumping of large volumes of fluids into these 735formations under high pressure. Water and sand represent 98 to $99.5 \%$ of the fluid used in 736hydraulic fracturing. Additional additives may include acids to remove drilling mud near the 737wellbore and biocides to prevent deleterious microbial activity (Davies, 2011). A portion of 738the so-called "fracking" fluids remains in the formation after the completion of the fracturing 739process, offering the opportunity to introduce a microbial consortium into the induced 740fractures, as part of a nutrient-delivery system, or more broadly, to modify the 741biogeochemical conditions in the formation. Such use of hydraulic fracturing should consider 742alternative solutions to the addition of biocide, typically used to prevent sulfide production 743that potentially increase human and environmental health risks, corrosion, and costly 744degradation of product quality. Possible strategies to prevent sulfide production could be to 745eliminate sulfur-containing compounds from the drilling mud. For example, dolomite could 746be substituted for barite when adding weight to bentonite-based drilling mud and, 747lignosulfonates could be replaced with polyphosphates, leonardite, and tannins 748(Struchtemeyer et al., 2011). In spite of the importance of hydraulic fracturing, very little is 749known about the microbiological consequences of this process. Increasing permeability helps 750facilitate $\mathrm{CH}_{4}$ production (i.e., enhances transport of gas to the wellbore (Solano-Acosta et al., 7512007), and would likely help carry injected nutrients, water, and/or microorganisms to 752additional coal surfaces. Currently, there are only few studies that evaluate the change in the 
753microbial composition of fracking fluids before and after the fracking process (Davis et al., 7542012; Struchtemeyer and Elshahed, 2012; Struchtemeyer et al., 2012, 2011), but none of 755them aim to enhance the engineering of fracking practices to stimulate microbial processes.

756

\subsection{Increasing the bioavailability of OM}

758The biotic and abiotic process of breaking down OM into methanogenic intermediates is 759often considered a rate-limiting step in methanogenesis (Scott, 1999; Strapoć et al., 2011a; 760Wawrik et al., 2012). Increasing the bioavailability of complex geopolymers could be 761accomplished through the addition of chemicals to dissolve the coal/shale matrix (Scott, 7621999). Laboratory studies have suggested that the addition of a strong oxidant, such as 763potassium permanganate (Huang et al., 2013) or hydrogen peroxide (Jones et al., 2013) may 764help to convert coal carbon to organic acids, although such chemicals could potentially be 765harmful to methanogens. The addition of surfactants was also tested to reduce surface and 766interfacial tensions between coal molecules (Papendick et al., 2011; Singh and Tripathi, 7672013), however, surfactant micelles can trap substrates and actually reduce their 768bioavailability in some cases (Mihelcic et al., 1993).

769

\section{Conclusions}

\section{1}

772While recent studies have helped to clarify the role of various microbial populations in 773conventional oil reservoir, the broader implications for SG and CBM production are still not 774understood. Laboratory-based and commercial projects studies regarding the stimulation of 775microbial methanogenesis has significantly increased our knowledge about the processes that 776lead to microbial $\mathrm{CH}_{4}$ generation from complex OM. Laboratory-based research has provided 777insight into locations and environments where microbial $\mathrm{CH}_{4}$ was observed, the microbial 
778communities involved and the metabolic pathways that lead to methane production. 779Commercial projects showed that microbial methane production in unconventional gas basin 780is significant and can be stimulated in situ. Yet, there are very few published shale reservoir 781microbiology studies, highlighting the need for novel insight into guiding practical strategies 782for enhanced gas recovery and for mitigating undesirable microbial processes and 783environmental impact. Any shallow, low temperature SG and CBM basin represent the 784opportunity for microbial methane stimulation. Shallow gas wells are relatively inexpensive 785to drill compared to deep basin; as a consequence, biogenic gas systems represent an 786important component in the mix of natural gas accumulations that will ultimately meet high 787demands of gas. Shale and coal vary greatly in terms of their physical, geochemical and 788biological characteristics. Studies on the in situ stimulation of microbial methane production 789should consider the compilation of studies discussed in this review. Current available 790technologies such as hydraulic fracturing could be adapted and used to stimulate microbial 791methanogenesis in shallow unconventional systems. Most of the biological activity in SG and 792CBM occurs in fractures and at the interface between the source rock and more permeable 793formations, where the pore size is greater, as well as the availability of water. Hydraulic 794fracturing, typically used to increase the permeability and the fractures network of SG 795formations, could be adapted to increase the contact surface area of microorganisms with the 796shale/coal interface and to guarantee a greater accessibility of OM for biodegradative 797microorganisms. Further research should be focused on issues related to the implementation 798and sustainability of hydraulic fracturing process. Intensified concerns by the public have 799prompted some companies to develop more environmentally friendly fracturing fluids. 800Halliburton, for example, is testing its CleanStim ${ }^{\circledR}$ formulation, composed of ingredients 801sourced from the food industry. Similarly, Chesapeake Energy eliminated $18 \%$ of the 802chemical additives used in hydraulic fracturing fluids thanks to their GreenFrac ${ }^{\circledR}$ initiative. 
803FracFocus, a web-based registry with support from the U.S. Department of Energy, provides 804details on the additives, chemicals and the amount of water typically used in the hydraulic 805fracturing process.

806Research into the microbiology of unconventional gas systems is a new interesting topic for 807engineers and scientists. Despite the similarities with conventional petroleum microbiology, 808there are many research questions regarding the bioavailability of OM, what specific 809microbial communities lead to methane production and their metabolic pathways. Moreover, 810research on water resources and wastewater management are still an issue. The answers to 811these research questions have implications for both enhanced recovery of gas and sustainable 812development of unconventional gas resources.

813

\section{Acknowledgements}

815

816The authors thank WSP Parsons Brinckerhoff, the Scottish Funding Council, the University 817of Strathclyde and the University of Manchester for supporting and funding this work. We 818also thank the British Geological Survey (BGS), which provided shale samples for 819preliminary analyses.

820

\section{References}

822

823Abu Laban, N., Selesi, D., Jobelius, C., Meckenstock, R.U., 2009. Anaerobic benzene degradation by Gram824 positive sulfate-reducing bacteria. FEMS Microbiol. Ecol. 68, 300-311. doi:10.1111/j.1574-

$825 \quad 6941.2009 .00672 . x$

826Alain, K., Harder, J., Widdel, F., Zengler, K., 2012. Anaerobic utilization of toluene by marine alpha- and 827 gammaproteobacteria reducing nitrate. Microbiology 158, 2946-2957. doi:10.1099/mic.0.061598-0 828An, D., Caffrey, S.M., Soh, J., Agrawal, A., Brown, D., Budwill, K., Dong, X., Dunfield, P.F., Foght, J., Gieg, 
829 L.M., Hallam, S.J., Hanson, N.W., He, Z., Jack, T.R., Klassen, J., Konwar, K.M., Kuatsjah, E., Li, C.,

830 Larter, S., Leopatra, V., Nesbø, C.L., Oldenburg, T., Pagé, A.P., Ramos-Padron, E., Rochman, F.F., Saidi-

831 Mehrabad, A., Sensen, C.W., Sipahimalani, P., Song, Y.C., Wilson, S., Wolbring, G., Wong, M.L.,

832 Voordouw, G., 2013. Metagenomics of hydrocarbon resource environments indicates aerobic taxa and

833 genes to be unexpectedly common. Environ. Sci. Technol. 47, 10708-10717. doi:10.1021/es4020184

834Annweiler, E., Michaelis, W., Meckenstock, R.U., 2002. Identical ring cleavage products during anaerobic

835 degradation of naphthalene, 2-methylnaphthalene, and tetralin indicate a new metabolic pathway. Appl

836 Env. Microbiol 68, 852-858. doi:Doi 10.1128/Aem.68.2.852-858.2002

837Ball, H.A., Johnson, H.A., Reinhard, M., Spormann, A.M., 1996. Initial reactions in anaerobic ethylbenzene

838 oxidation by a denitrifying bacterium, strain EB1. J. Bacteriol. 178, 5755-5761.

839Barnhart, E.P., De León, K.B., Ramsay, B.D., Cunningham, A.B., Fields, M.W., 2013. Investigation of coal-

840 associated bacterial and archaeal populations from a diffusive microbial sampler (DMS). Int. J. Coal Geol.

841 115, 64-70. doi:10.1016/j.coal.2013.03.006

842Baublys, K.A., Hamilton, S.K., Golding, S.D., Vink, S., Esterle, J., 2015. Microbial controls on the origin and

843 evolution of coal seam gases and production waters of the Walloon Subgroup; Surat Basin, Australia. Int.

844 J. Coal Geol. 147, 85-104. doi: 10.1016/j.coal.2015.06.007

845Beckmann, S., Lueders, T., Krüger, M., von Netzer, F., Engelen, B., Cypionka, H., 2011. Acetogens and

846 acetoclastic Methanosarcinales govern methane formation in abandoned coal mines. Appl. Environ.

847 Microbiol. 77, 3749-3756. doi:10.1128/AEM.02818-10

848Beliveau, D., 1993. Honey, I Shrunk the Pores! J. Can. Pet. Technol. 32, 15-17.

849Beller, H.R., Edwards, E. a, 2000. Anaerobic toluene activation by benzylsuccinate synthase in a highly

850 enriched methanogenic culture. Appl. Environ. Microbiol. 66, 5503-5.

851Bergmann, F., Selesi, D., Weinmaier, T., Tischler, P., Rattei, T., Meckenstock, R.U., 2011. Genomic insights into

852 the metabolic potential of the polycyclic aromatic hydrocarbon degrading sulfate-reducing

853 Deltaproteobacterium N47. Environ. Microbiol. 13, 1125-1137. doi:10.1111/j.1462-2920.2010.02391.x

854Brown, A., 2011. Identification of source carbon for microbial methane in unconventional gas reservoirs. Am.

855 Assoc. Pet. Geol. Bull. 95, 1321-1338. doi:10.1306/01191110014

856Burke, R.A., Barber, T.R., Sackett, W.M., 1988. Methane flux and stable hydrogen and carbon isotope

857 composition of sedimentary methane from the Florida Everglades. Global Biogeochem. Cycles 2, 329.

858 doi:10.1029/GB002i004p00329 
859Bustin, R., Bustin, A., Cui, A., Ross, D., Pathi, V., 2008. Impact of shale properties on pore structure and storage 860 characteristics. SPE Shale Gas Prod. Conf. SPE 119892. doi:10.2118/119892-MS

861Bustin, R.., Clarkson, C.., 1998. Geological controls on coalbed methane reservoir capacity and gas content. Int.

862 J. Coal Geol. 38, 3-26. doi:10.1016/S0166-5162(98)00030-5

863Chalmers, G.R., Bustin, R.M., Power, I.M., 2012. Characterization of gas shale pore systems by porosimetry,

864 pycnometry, surface area, and field emission scanning electron microscopy/transmission electron

865 microscopy image analyses: Examples from the Barnett, Woodford, Haynesville, Marcellus, and Doig uni.

866 Am. Assoc. Pet. Geol. Bull. 96, 1099-1119. doi:10.1306/10171111052

867Chalmers, G.R.L., Bustin, R.M., 2008. Lower Cretaceous gas shales in northeastern British Columbia, Part I:

868 geological controls on methane sorption capacity. Bull. Can. Pet. Geol. 56, 1-21.

869 doi:10.2113/gscpgbull.56.1.1

870Chalmers, G.R.L., Bustin, R.M., 2007. The organic matter distribution and methane capacity of the Lower

871 Cretaceous strata of Northeastern British Columbia, Canada. Int. J. Coal Geol. 70, 223-239.

872 doi:10.1016/j.coal.2006.05.001

873Chalmers, G.R.L., Marc Bustin, R., 2007. On the effects of petrographic composition on coalbed methane 874 sorption. Int. J. Coal Geol. 69, 288-304. doi:10.1016/j.coal.2006.06.002

875Chang Shiung, L. C and Yuan, S.Y., B. V, 2002. Anaerobic biodegradation of polycyclic aromatic hydrocarbon 876 in soil. Chemosphere 48, 717-724. doi:10.1016/S0045-6535(02)00151-0

877Civan, F., Rai, C.S., Sondergeld, C.H., 2011. Shale-Gas Permeability and Diffusivity Inferred by Improved

878 Formulation of Relevant Retention and Transport Mechanisms. Transp. Porous Media 86, 925-944.

879 doi:10.1007/s11242-010-9665-X

880Clarkson, C.R., Bustin, R.M., 1996. Variation in micropore capacity and size distribution with composition in

881 bituminous coal of the Western Canadian Sedimentary Basin: Implications for coalbed methane potential.

882 Fuel 75, 1483-1498. doi:10.1016/0016-2361(96)00142-1

883Claypool, G.E., Kaplan, I.R., 1974. The origin and distribution of methane in marine sediments, in: Natural

884 Gases in Marine Sediments - Marine Science Volume 3. Springer US, Boston, MA, pp. 99-139.

885 doi:10.1007/978-1-4684-2757-8_8

886Coates, J.D., Lonergan, D.J., Philips, E.J., Jenter, H., Lovley, D.R., 1995. Desulfuromonas palmitatis sp. nov., a

887 marine dissimilatory Fe(III) reducer that can oxidize long-chain fatty acids. Arch. Microbiol. 164, 406-13.

888 doi:10.1007/s002030050282 
889Coleman, D.D., Liu, C.-L., Riley, K.M., 1988. Microbial methane in the shallow Paleozoic sediments and 890 glacial deposits of Illinois, U.S.A. Chem. Geol. 71, 23-40. doi:10.1016/0009-2541(88)90103-9

891Conrad, R., Bak, F., Seitz, H.J., Thebrath, B., Mayer, H.P., Schütz, H., 1989. Hydrogen turnover by

892 psychrotrophic homoacetogenic and mesophilic methanogenic bacteria in anoxic paddy soil and lake

893 sediment. FEMS Microbiol. Lett. 62, 285-293. doi:10.1111/j.1574-6968.1989.tb03382.x

894Conrad, R., Klose, M., 2005. Effect of potassium phosphate fertilization on production and emission of methane

895 and its 13C-stable isotope composition in rice microcosms. Soil Biol. Biochem. 37, 2099-2108.

896 doi:10.1016/j.soilbio.2005.03.012

897Conrad, R., Schütz, H., Babbel, M., 1987. Temperature limitation of hydrogen turnover and methanogenesis in 898 anoxic paddy soil. FEMS Microbiol. Lett. 45, 281-289. doi:10.1016/0378-1097(87)90005-x

899Curtis, J.J.B., John B. Curtis1, 2002. Fractured shale-gas systems. Am. Assoc. Pet. Geol. Bull. 86, $1921-1938$. 900 doi:10.1306/61EEDDBE-173E-11D7-8645000102C1865D

901Davies, R.J., 2011. Methane contamination of drinking water caused by hydraulic fracturing remains unproven.

902 Proc. Natl. Acad. Sci. 108, E871-E871. doi:10.1073/pnas.1113299108

903Davis, J.P., Struchtemeyer, C.G., Elshahed, M.S., 2012. Bacterial communities associated with production

904 facilities of two newly drilled thermogenic natural gas wells in the Barnett Shale (Texas, USA). Microb.

905 Ecol. 64, 942-54. doi:10.1007/s00248-012-0073-3

906Deppenmeier, U., Lienard, T., Gottschalk, G., 1999. Novel reactions involved in energy conservation by

907 methanogenic archaea. FEBS Lett. 457, 291-297. doi:10.1016/S0014-5793(99)01026-1

908Doerfert, S.N., Reichlen, M., Iyer, P., Wang, M., Ferry, J.G., 2009. Methanolobus zinderi sp. nov., a

909 methylotrophic methanogen isolated from a deep subsurface coal seam. Int. J. Syst. Evol. Microbiol. 59,

910 1064-1069. doi:10.1099/ijs.0.003772-0

911Drake, H.L., Horn, M. a, Wüst, P.K., 2009. Intermediary ecosystem metabolism as a main driver of

912 methanogenesis in acidic wetland soil. Environ. Microbiol. Rep. 1, 307-318. doi:10.1111/j.1758-

$913 \quad 2229.2009 .00050 . x$

914Elshahed, M.S., McInerney, M.J., 2001. Benzoate fermentation by the anaerobic bacterium Syntrophus

915 aciditrophicus in the absence of hydrogen-using microorganisms. Appl. Environ. Microbiol. 67, 5520-

916 5525. doi:Doi 10.1128/Aem.67.12.5520-5525.2001

917Faiz, M., Hendry, P., 2006. Significance of microbial activity in Australian coal bed methane reservoirs -- a

918 review . Bull. Can. Pet. Geol. 54, 261-272. doi:10.2113/gscpgbull.54.3.261 
919Fakoussa, R.M., Hofrichter, M., 1999. Biotechnology and microbiology of coal degradation. Appl. Microbiol. 920 Biotechnol. 52, 25-40. doi:10.1007/s002530051483

921Fallgren, P.H., Jin, S., Zeng, C., Ren, Z., Lu, A., Colberg, P.J.S., 2013a. Comparison of coal rank for enhanced 922 biogenic natural gas production. Int. J. Coal Geol. 115, 92-96. doi:10.1016/j.coal.2013.01.014

923Fichter, J., Moore, R., Summer, E., n.d. How Hot is Too Hot for Bacteria.

924Flores, R.M., Rice, C. a., Stricker, G.D., Warden, A., Ellis, M.S., 2008. Methanogenic pathways of coal-bed gas 925 in the Powder River Basin, United States: The geologic factor. Int. J. Coal Geol. 76, 52-75.

926 doi:10.1016/j.coal.2008.02.005

927Formolo, M., Martini, A., Petsch, S., 2008. Biodegradation of sedimentary organic matter associated with 928 coalbed methane in the Powder River and San Juan Basins, USA. Int. J. Coal Geol. 76, 86-97.

929 doi:10.1016/j.coal.2008.03.005

930Francis, a J., Dodge, C.J., 1988. Anaerobic microbial dissolution of transition and heavy metal oxides. Appl. 931 Environ. Microbiol. 54, 1009-14.

932Fredrickson, J.K., McKinley, J.P., Bjornstad, B.N., Long, P.E., Ringelberg, D.B., White, D.C., Krumholz, L.R., 933 Suflita, J.M., Colwell, F.S., Lehman, R.M., Phelps, T.J., Onstott, T.C., 1997. Frederickson_et_al_1997.pdf. 934 Geomicrobiology 14, 183-202.

935Gao, B., Mohan, R., Gupta, R.S., 2009. Phylogenomics and protein signatures elucidating the evolutionary 936 relationships among the Gammaproteobacteria. Int. J. Syst. Evol. Microbiol. 59, 234-247.

937 doi:10.1099/ijs.0.002741-0

938Garcia, J.-L., Ollivier, B., Whitman, W.B., 2006. The Order Methanomicrobiales, in: The Prokaryotes. Springer 939 New York, New York, NY, pp. 208-230. doi:10.1007/0-387-30743-5_10

940GB Marsh, AJ Fanelli, JN Armor, P.Z., 1987. Spray-dried inorganic oxides from non-aqueous gels or solutions. 941 US4713233 A.

942Genthner, B.R.S., Townsend, G.T., Lantz, S.E., Mueller, J.G., 1997. Persistence of Polycyclic Aromatic 943 Hydrocarbon Components of Creosote Under Anaerobic Enrichment Conditions. Arch. Environ. Contam. 944 Toxicol. 32, 99-105. doi:10.1007/s002449900160

945Gieg, L.M., Davidova, I. a., Duncan, K.E., Suflita, J.M., 2010. Methanogenesis, sulfate reduction and crude oil 946 biodegradation in hot Alaskan oilfields. Environ. Microbiol. 12, 3074-3086. doi:10.1111/j.1462$947 \quad 2920.2010 .02282 . x$

948Golding, S.D., Boreham, C.J., Esterle, J.S., 2013. Stable isotope geochemistry of coal bed and shale gas and 
950Grabowski, A., Nercessian, O., Fayolle, F., Blanchet, D., Jeanthon, C., 2005. Microbial diversity in production 951 waters of a low-temperature biodegraded oil reservoir. FEMS Microbiol. Ecol. 54, 427-443.

952 doi:10.1016/j.femsec.2005.05.007

953Grbić-Galić, D., Vogel, T.M., 1987. Transformation of toluene and benzene by mixed methanogenic cultures. 954 Appl. Environ. Microbiol. 53, 254-60.

955Green, M.S., Flanegan, K.C., Gilcrease, P.C., 2008. Characterization of a methanogenic consortium enriched 956 from a coalbed methane well in the Powder River Basin, U.S.A. Int. J. Coal Geol. 76, 34-45.

957 doi:10.1016/j.coal.2008.05.001

958Gross, D., Sachsenhofer, R.F., Bechtel, A., Pytlak, L., Rupprecht, B., Wegerer, E., 2015. Organic geochemistry 959 of Mississippian shales (Bowland Shale Formation) in central Britain: Implications for depositional 960 environment, source rock and gas shale potential. Mar. Pet. Geol. 59, 1-21.

961 doi:10.1016/j.marpetgeo.2014.07.022

962Grunau, H.R., 1983. Natural gas in major basins worldwide attributed to source rock type, thermal history and 963 bacterial origin, in: 11th World Petroleum Congress. p. 10.

964Guo, H., Liu, R., Yu, Z., Zhang, H., Yun, J., Li, Y., Liu, X., Pan, J., 2012a. Pyrosequencing reveals the 965 dominance of methylotrophic methanogenesis in a coal bed methane reservoir associated with Eastern 966 Ordos Basin in China. Int. J. Coal Geol. 93, 56-61. doi:10.1016/j.coal.2012.01.014

967Guo, H., Yu, Z., Liu, R., Zhang, H., Zhong, Q., Xiong, Z., 2012b. Methylotrophic methanogenesis governs the 968 biogenic coal bed methane formation in Eastern Ordos Basin, China. Appl. Microbiol. Biotechnol. 96, 969 1587-97. doi:10.1007/s00253-012-3889-3

970Haack, S., Breznak, J., 1993. Cytophaga xylanolytica sp. nov., a xylan-degrading, anaerobic gliding bacterium. 971 Arch. Microbiol. 159, 6-15. doi:10.1007/BF00244257

972Hamilton, S.K., Golding, S.D., Baublys, K.A., Esterle, J.S., 2015. Conceptual exploration targeting for 973 microbially enhanced coal bed methane (MECoM) in the Walloon Subgroup, eastern Surat Basin, 974 Australia. Int. J. Coal Geol. 138, 68-82. doi:10.1016/j.coal.2014.12.002

975Hamilton, S.K., Golding, S.D., Baublys, K.A., Esterle, J.S., 2014. Stable isotopic and molecular composition of 976 desorbed coal seam gases from the Walloon Subgroup, eastern Surat Basin, Australia. Int. J. Coal Geol. 122, 21-36. doi:http://dx.doi.org/10.1016/j.coal.2013.12.003

978Harder, J., 2000. Anaerobic utilization of essential oils by denitrifying bacteria. Biodegradation 11, 55-63. 
980Haritash, A.K., Kaushik, C.P., 2009. Biodegradation aspects of Polycyclic Aromatic Hydrocarbons (PAHs): A 981 review. J. Hazard. Mater. 169, 1-15. doi:10.1016/j.jhazmat.2009.03.137

982Harris, S.H., Smith, R.L., Barker, C.E., 2008. Microbial and chemical factors influencing methane production in 983 laboratory incubations of low-rank subsurface coals. Int. J. Coal Geol. 76, 46-51.

984 doi:10.1016/j.coal.2008.05.019

985Head, I.M., Jones, D.M., Larter, S.R., 2003. Biological activity in the deep subsurface and the origin of heavy 986 oil. Nature 426, 344-352. doi:10.1038/nature02134

987Hoehler, T.M., Alperin, M.J., 1996. Anaerobic methane oxidation by a methanogen-sulfate reducer consortium: 988 geochemical evidence and biochemical considerations, in: Microbial Growth on C1 Compounds. Springer

989 Netherlands, Dordrecht, pp. 326-333. doi:10.1007/978-94-009-0213-8_43

990Hoehler, T.M., Alperin, M.J., Albert, D.B., Martens, C.S., 1998. Thermodynamic control on hydrogen

991 concentrations in anoxic sediments. Geochim. Cosmochim. Acta 62, 1745-1756. doi:10.1016/S0016-

$992 \quad 7037(98) 00106-9$

993Holmes, D.E., Nevin, K.P., Woodard, T.L., Peacock, A.D., Lovley, D.R., 2007. Prolixibacter bellariivorans gen. 994 nov., sp. nov., a sugar-fermenting, psychrotolerant anaerobe of the phylum Bacteroidetes, isolated from a

995 marine-sediment fuel cell. Int. J. Syst. Evol. Microbiol. 57, 701-707. doi:10.1099/ijs.0.64296-0

996Hover, V.C., 1996. Relationship Between Organic Matter And authigenic Illite Smectite in Devonian Black 997 Shales, Michigan and Illinois Basins, USA. 56576.

998Huang, Z., Urynowicz, M. a., Colberg, P.J.S., 2013. Stimulation of biogenic methane generation in coal samples 999 following chemical treatment with potassium permanganate. Fuel 111, 813-819.

1000 doi:http://dx.doi.org/10.1016/j.fuel.2013.03.079

1001Hunt, J.R., Holden, P. a, Firestone, M.K., 1995. Coupling transport and biodegradation of VOCs in surface and 1002 subsurface soils., in: Environmental Health Perspectives. pp. 75-8.

1003Hylemon, P.B., Harder, J., 1998. Biotransformation of monoterpenes, bile acids, and other isoprenoids in 1004 anaerobic ecosystems. FEMS Microbiol. Rev. 22, 475-88. doi:10.1016/S0168-6445(98)00027-8 1005Jaekel, U., Musat, N., Adam, B., Kuypers, M., Grundmann, O., Musat, F., 2013. Anaerobic degradation of 1006 propane and butane by sulfate-reducing bacteria enriched from marine hydrocarbon cold seeps. ISME J. 7, 1007 885-95. doi:10.1038/ismej.2012.159

1008Jarvie, D.M., Hill, R.J., Ruble, T.E., Pollastro, R.M., 2007. Unconventional shale-gas systems: The 
1011Javadpour, F., 2009. Nanopores and apparent permeability of gas flow in mudrocks (shales and siltstone). J.

1012 Can. Pet. Technol. 1-6.

1013Jenden, P.D., Newell, K.D., Kaplan, I.R., Watney, W.L., 1988. Composition and stable-isotope geochemistry of 1014 natural gases from Kansas, Midcontinent, U.S.A. Chem. Geol. 71, 117-147. doi:10.1016/0009-

1015 2541(88)90110-6

1016Jenkins, C., Boyer II, C., 2008. Coalbed- and Shale-Gas Reservoirs. J. Pet. Technol. 60, 92-99.

1017 doi:10.2118/103514-MS

1018Jenneman, G.E., McInerney, M.J., Knapp, R.M., 1985. Microbial Penetration through Nutrient-Saturated Berea 1019 Sandstone. Appl. Envir. Microbiol. 50, 383-391.

1020Jin, H., Schimmelmann, A., Mastalerz, M., Pope, J., Moore, T.A., 2010. Coalbed gas desorption in canisters:

1021 Consumption of trapped atmospheric oxygen and implications for measured gas quality. Int. J. Coal Geol. 1022 81, 64-72. doi:10.1016/j.coal.2009.10.010

1023Johnsen, A.R., Wick, L.Y., Harms, H., 2005. Principles of microbial PAH-degradation in soil. Environ. Pollut. 1024 133, 71-84. doi:10.1016/j.envpol.2004.04.015

1025Jones, E.J.P., Harris, S.H., Barnhart, E.P., Orem, W.H., Clark, A.C., Corum, M.D., Kirshtein, J.D., Varonka, 1026 M.S., Voytek, M. a., 2013. The effect of coal bed dewatering and partial oxidation on biogenic methane 1027 potential. Int. J. Coal Geol. 115, 54-63. doi:10.1016/j.coal.2013.03.011

1028Jones, E.J.P., Voytek, M. a, Corum, M.D., Orem, W.H., 2010. Stimulation of methane generation from 1029 nonproductive coal by addition of nutrients or a microbial consortium. Appl. Environ. Microbiol. 76, 1030 7013-22. doi:10.1128/AEM.00728-10

1031Jones, E.J.P., Voytek, M. a., Warwick, P.D., Corum, M.D., Cohn, A., Bunnell, J.E., Clark, A.C., Orem, W.H., 1032 2008. Bioassay for estimating the biogenic methane-generating potential of coal samples. Int. J. Coal 1033 Geol. 76, 138-150. doi:10.1016/j.coal.2008.05.011

1034Kersters, K., De Vos, P., Gillis, M., Swings, J., Vandamme, P., Stakebrandt, E., 2006. Introduction to the 1035 Proteobacteria, Prokaryotes Vol. 5. doi:10.1007/0-387-30745-1_1 noi

1036Kim, S., Stanford, L. a., Rodgers, R.P., Marshall, A.G., Walters, C.C., Qian, K., Wenger, L.M., Mankiewicz, P., 1037 2005. Microbial alteration of the acidic and neutral polar NSO compounds revealed by Fourier transform 1038 ion cyclotron resonance mass spectrometry. Org. Geochem. 36, 1117-1134. 
1040Kinnon, E.C.P., Golding, S.D., Boreham, C.J., Baublys, K.A., Esterle, J.S., 2010. Stable isotope and water 1041 quality analysis of coal bed methane production waters and gases from the Bowen Basin, Australia. Int. J. 1042 Coal Geol. 82, 219-231. doi:10.1016/j.coal.2009.10.014

1043Kirk, M.F., Martini, A.M., Breecker, D.O., Colman, D.R., Takacs-Vesbach, C., Petsch, S.T., 2012. Impact of 1044 commercial natural gas production on geochemistry and microbiology in a shale-gas reservoir. Chem. 1045 Geol. 332-333, 15-25. doi:10.1016/j.chemgeo.2012.08.032

1046Kniemeyer, O., Heider, J., 2001. Ethylbenzene dehydrogenase, a novel hydrocarbon-oxidizing 1047 molybdenum/iron-sulfur/heme enzyme. J. Biol. Chem. 276, 21381-6. doi:10.1074/jbc.M101679200 1048Krüger, M., van Berk, W., Arning, E.T., Jiménez, N., Schovsbo, N.H., Straaten, N., Schulz, H.-M., 2014. The 1049 biogenic methane potential of European gas shale analogues: Results from incubation experiments and 1050 thermodynamic modelling. Int. J. Coal Geol. 136, 59-74. doi:10.1016/j.coal.2014.09.012 1051Krumholz, L., 2000. Microbial communities in the deep subsurface. Hydrogeol. J. 8, 4-10. 1052 doi:10.1007/s100400050003

1053Krumholz, L.R., Harris, S.H., Suflita, J.M., 2002. Anaerobic Microbial Growth from Components of Cretaceous 1054 Shales. Geomicrobiol. J. 19, 593-602. doi:10.1080/01490450290098559

1055Krumholz, L.R., McKinley, J.P., Ulrich, G.A., M., S.J., 1997. Confined subsurface microbial communities in 1056 Cretaceous rock. Nature 386, 64-66. doi:10.1038/386064a0

1057Kuivila, K.M., Murray, J.W., Devol, A.H., Novelli, P.C., 1989. Methane production, sulfate reduction and 1058 competition for substrates in the sediments of Lake Washington. Geochim. Cosmochim. Acta 53, 4091059 416. doi:10.1016/0016-7037(89)90392-X

1060Küsel, K., Dorsch, T., Acker, G., Stackebrandt, E., Drake, H.L., 2000. Clostridium scatologenes strain SL1 1061 isolated as an acetogenic bacterium from acidic sediments. Int. J. Syst. Evol. Microbiol. 50, 537-546. 1062 doi:10.1099/00207713-50-2-537

1063Lamberson, M.N., Bustin, R.M., 1993. Coalbed methane characteristics of Gates Formation Coals, Northeastern 1064 British Columbia: effect of maceral composition. Am. Assoc. Pet. Geol. Bull. 77, 2062-2077. doi:10.1306/BDFF8FD8-1718-11D7-8645000102C1865D

1066Larsen, J.W., Hall, P., Wernett, P.C., 1995. Pore Structure of the Argonne Premium Coals. Energy \& Fuels 9, 1067 324-330. doi:10.1021/ef00050a018

1068Laxminarayana, C., Crosdale, P.J., 1999. Role of coal type and rank on methane sorption characteristics of 
1070Levine, J.R., 1996. Model study of the influence of matrix shrinkage on absolute permeability of coal bed 1071 reservoirs. Geol. Soc. London, Spec. Publ. doi:10.1144/GSL.SP.1996.109.01.14

1072Levy, J.H., Day, S.J., Killingley, J.S., 1997. Methane capacities of Bowen Basin coals related to coal properties. 1073 Fuel 76, 813-819. doi:10.1016/S0016-2361(97)00078-1

1074Li, D., Hendry, P., Faiz, M., 2008. A survey of the microbial populations in some Australian coalbed methane 1075 reservoirs. Int. J. Coal Geol. 76, 14-24. doi:10.1016/j.coal.2008.04.007

1076Liu, S., Suflita, J.M., 1993. H(2)-CO(2)-Dependent Anaerobic O-Demethylation Activity in Subsurface 1077 Sediments and by an Isolated Bacterium. Appl. Environ. Microbiol. 59, 1325-31.

1078Lovley, D.R., Chapelle, F.H., 1995. Deep subsurface microbial processes. Rev. Geophys. 33, 365-381. 1079 doi:10.1016/S0168-6445(97)00013-2

1080Lovley, D.R., Goodwin, S., 1988. Hydrogen concentrations as an indicator of the predominant terminal electron1081 accepting reactions in aquatic sediments. Geochim. Cosmochim. Acta 52, 2993-3003. doi:10.1016/0016$1082 \quad 7037(88) 90163-9$

1083Lovley, D.R., Holmes, D.E., Nevin, K.P., 1991. Dissimilatory Fe(III) and Mn(IV) reduction. Microbiol. Rev. 55, 1084 259-287. doi:10.1016/S0065-2911(04)49005-5

1085Lovley, D.R., Lonergan, D.J., 1990. Anaerobic oxidation of toluene, phenol, and p-cresol by the dissimilatory 1086 iron-reducing organism, GS-15. Appl. Environ. Microbiol. 56, 1858-1864.

1087Lovley, D.R., Phillips, E.J., 1987. Rapid assay for microbially reducible ferric iron in aquatic sediments. Appl. 1088 Environ. Microbiol. 53, 1536-1540. doi:10.1007/BF01611203

1089Mah, R.A., Ward, D.M., Baresi, L., Glass, T.L., 1977. Biogenesis of methane. Ann. Rev. Microbiol. 31, 3091090 341. doi:10.1146/annurev.mi.31.100177.001521

1091Mahaffey, W., Bradfish, J. A., Haveman, S. A., Sutton, B. C., \& Greaser, L., 2013. Dispersion of compounds for 1092 the stimulation of biogenic gas generation in deposits of carbonaceous material. US 13/847,756.

1093Martens, C.S., Berner, R.A., 1974. Methane production in the interstitial waters of sulfate-depleted marine 1094 sediments. Science (80-. ). 185, 1167-1169. doi:10.1126/science.185.4157.1167

1095Martini, A., Walter, L., Budai, J., 1998. Genetic and temporal relations between formation waters and biogenic 1096 methane: Upper Devonian Antrim Shale, Michigan Basin, USA. Geochim. Cosmochim. Acta Cosmochim. 1097 Acta 62, 1699-1720.

1098Martini, A.M., Budai, J.M., Walter, L.M., Schoell, M., 1996. Microbial generation of economic accumulations 
1100Martini, A.M., Walter, L.M., Ku, T.C.W., Budai, J.M., McIntosh, J.C., Schoell, M., 2003. Microbial production 1101 and modification of gases in sedimentary basins: A geochemical case study from a Devonian shale gas 1102 play, Michigan basin. Am. Assoc. Pet. Geol. Bull. 87, 1355-1375. doi:10.1306/031903200184

1103Martini, A.M., Walter, L.M., McIntosh, J.C., 2008. Identification of microbial and thermogenic gas components 1104 from Upper Devonian black shale cores, Illinois and Michigan basins. Am. Assoc. Pet. Geol. Bull. 92, 1105 327-339. doi:10.1306/10180706037

1106Mastalerz, M., Drobniak, A., Strąpoć, D., Solano Acosta, W., Rupp, J., 2008. Variations in pore characteristics in 1107 high volatile bituminous coals: Implications for coal bed gas content. Int. J. Coal Geol. 76, $205-216$.

1108 doi:10.1016/j.coal.2008.07.006

1109Mattavelli, L., Ricchiuto, T., \& Martinenghi, C., 1992. Deep isotopic light methane in northern Italy, in:

$1110 \quad$ Bacterial Gas. p. R. Vially 121-132.

1111Mayumi, D., Mochimaru, H., Yoshioka, H., Sakata, S., Maeda, H., Miyagawa, Y., Ikarashi, M., Takeuchi, M.,

1112 Kamagata, Y., 2011. Evidence for syntrophic acetate oxidation coupled to hydrogenotrophic

1113 methanogenesis in the high-temperature petroleum reservoir of Yabase oil field (Japan). Environ.

1114 Microbiol. 13, 1995-2006. doi:10.1111/j.1462-2920.2010.02338.x

1115Mbadinga, S.M., Wang, L.Y., Zhou, L., Liu, J.F., Gu, J.D., Mu, B.Z., 2011. Microbial communities involved in 1116 anaerobic degradation of alkanes. Int. Biodeterior. Biodegrad. 65, 1-13. doi:10.1016/j.ibiod.2010.11.009 1117McInerney, M.J., Bryant, M.P., 1981. Anaerobic Degradation of Lactate by Syntrophic Associations of 1118 Methanosarcina barkeri and Desulfovibrio Species and Effect of H(2) on Acetate Degradation. Appl. 1119 Environ. Microbiol. 41, 346-54.

1120McInerney, M.J., Rohlin, L., Mouttaki, H., Kim, U., Krupp, R.S., Rios-Hernandez, L., Sieber, J., Struchtemeyer, 1121 C.G., Bhattacharyya, A., Campbell, J.W., Gunsalus, R.P., 2007. The genome of Syntrophus aciditrophicus: 1122 life at the thermodynamic limit of microbial growth. Proc. Natl. Acad. Sci. U. S. A. 104, 7600-5. doi:10.1073/pnas.0610456104

1124McInerney, M.J., Sieber, J.R., Gunsalus, R.P., 2009. Syntrophy in anaerobic global carbon cycles. Curr. Opin. Biotechnol. 20, 623-32. doi:10.1016/j.copbio.2009.10.001

1126McInerney, M.J., Struchtemeyer, C.G., Sieber, J., Mouttaki, H., Stams, A.J.M., Schink, B., Rohlin, L., Gunsalus, 1127 R.P., 2008. Physiology, ecology, phylogeny, and genomics of microorganisms capable of syntrophic metabolism. Ann. N. Y. Acad. Sci. 1125, 58-72. doi:10.1196/annals.1419.005 
1129McIntosh, J., Martini, A., Petsch, S., Huang, R., Nuesslein, K., 2008. Biogeochemistry of the Forest City Basin 1130 coalbed methane play. Int. J. Coal Geol. 76, 111-118. doi:10.1016/j.coal.2008.03.004

1131McIntosh, J.C., Walter, L.M., Martini, a. M., 2002. Pleistocene recharge to midcontinent basins: Effects on

1132 salinity structure and microbial gas generation. Geochim. Cosmochim. Acta 66, 1681-1700.

1133 doi:10.1016/S0016-7037(01)00885-7

1134McIntosh, J.C., Warwick, P.D., Martini, a M., Osborn, S.G., 2010. Coupled hydrology and biogeochemistry of 1135 Paleocene-Eocene coal beds, northern Gulf of Mexico. Geol. Soc. Am. Bull. 122, 1248-1264.

1136 doi:10.1130/B30039.1

1137Meslé, M., Dromart, G., Haeseler, F., Oger, P.M., 2015. Classes of organic molecules targeted by a

1138 methanogenic microbial consortium grown on sedimentary rocks of various maturities. Front. Microbiol.

1139 6, 1-15. doi:10.3389/fmicb.2015.00589

1140Meslé, M., Dromart, G., Oger, P., 2013. Microbial methanogenesis in subsurface oil and coal. Res. Microbiol.

1141 164, 959-972. doi:10.1016/j.resmic.2013.07.004

1142Meslé, M., Périot, C., Dromart, G., Oger, P., 2013. Biostimulation to identify microbial communities involved in 1143 methane generation in shallow, kerogen-rich shales. J. Appl. Microbiol. 114, 55-70.

1144 doi:10.1111/jam.12015

1145Mihelcic, J.R., Lueking, D.R., Mitzell, R.J., Stapleton, J.M., 1993. Bioavailability of sorbed- and separate-phase 1146 chemicals. Biodegradation 4, 141-153. doi:10.1007/BF00695116

1147Milewska-duda, J., Duda, J., Nodzeski, A., Lakatos, J., Nodzen, A., 2000. Absorption and Adsorption of

1148 Methane and Carbon Dioxide in Hard Coal and Active Carbon. Langmuir 16, 5458-5466.

1149 doi:10.1021/la991515a

1150Milkov, A. V., 2011. Worldwide distribution and significance of secondary microbial methane formed during

1151 petroleum biodegradation in conventional reservoirs. Org. Geochem. 42, 184-207.

1152 doi:10.1016/j.orggeochem.2010.12.003

1153Mitterer, R.M., 2010. Methanogenesis and sulfate reduction in marine sediments: A new model. Earth Planet.

1154 Sci. Lett. 295, 358-366. doi:10.1016/j.epsl.2010.04.009

1155Mohebali, G., Ball, A.S., 2008. Biocatalytic desulfurization (BDS) of petrodiesel fuels. Microbiology 154, 1156 2169-2183. doi:10.1099/mic.0.2008/017608-0

1157Moore, T. a., 2012. Coalbed methane: A review. Int. J. Coal Geol. 101, 36-81. doi:10.1016/j.coal.2012.05.011

1158Müller, J. a, Schink, B., 2000. Initial steps in the fermentation of 3-hydroxybenzoate by Sporotomaculum 
1160Murali Mohan, A., Hartsock, A., Hammack, R.W., Vidic, R.D., Gregory, K.B., 2013. Microbial communities in 1161 flowback water impoundments from hydraulic fracturing for recovery of shale gas. FEMS Microbiol.

1162 Ecol. 86, 567-580. doi:10.1111/1574-6941.12183

1163Musat, F., Widdel, F., 2008. Anaerobic degradation of benzene by a marine sulfate-reducing enrichment culture, 1164 and cell hybridization of the dominant phylotype. Environ. Microbiol. 10, 10-19. doi:10.1111/j.1462$1165 \quad 2920.2007 .01425 . x$

1166Orem, W.H., Tatu, C. a., Lerch, H.E., Rice, C. a., Bartos, T.T., Bates, A.L., Tewalt, S., Corum, M.D., 2007. 1167 Organic compounds in produced waters from coalbed natural gas wells in the Powder River Basin, 1168 Wyoming, USA. Appl. Geochemistry 22, 2240-2256. doi:10.1016/j.apgeochem.2007.04.010 1169Orem, W.H., Voytek, M. a., Jones, E.J.P., Lerch, H.E., Bates, A.L., Corum, M.D., Warwick, P.D., Clark, A.C., 11702010 . Organic intermediates in the anaerobic biodegradation of coal to methane under laboratory 1171 conditions. Org. Geochem. 41, 997-1000. doi:http://dx.doi.org/10.1016/j.orggeochem.2010.03.005 1172Oremland, R., Polcin, S., 1982. Methanogenesis and sulfate reduction: competitive and noncompetitive 1173 substrates in estuarine sediments. Appl. Environ. Microbiol. 44:6, 1270-1276.

1174Osborn, S.G., McIntosh, J.C., 2010. Chemical and isotopic tracers of the contribution of microbial gas in 1175 Devonian organic-rich shales and reservoir sandstones, northern Appalachian Basin. Appl. Geochemistry $1176 \quad$ 25, 456-471. doi:10.1016/j.apgeochem.2010.01.001

1177Papendick, S.L., Downs, K.R., Vo, K.D., Hamilton, S.K., Dawson, G.K.W., Golding, S.D., Gilcrease, P.C., 2011. 1178 Biogenic methane potential for Surat Basin, Queensland coal seams. Int. J. Coal Geol. 88, $123-134$. 1179 doi:10.1016/j.coal.2011.09.005

1180Parkes, R.J., Cragg, B.A., Wellsbury, P., 2000. Recent studies on bacterial populations and processes in 1181 subseafloor sediments: A review. Hydrogeol. J. 8, 11-28. doi:Doi 10.1007/Pl00010971

1182Passey, Q.R., Bohacs, K.M., Esch, W.L., Klimentidis, R., Sinha, S., Upstream, E., 2010. From Oil-Prone Source 1183 Rock to Gas-Producing Shale Reservoir - Geologic and Petrophysical Characterization of Unconventional 1184 Shale-Gas Reservoirs, in: CPS/SPE International Oil \& Gas Conference and Exhibition in China 2010. pp. 1707-1735. doi:131350

1186Pearson, I., Zeniewski, P., Jrc, P.Z., Mcglade, C., Sorrell, S., Speirs, J., Thonhauser, G., 2012. Unconventional 1187 Gas: Potential Energy Market Impacts in the European Union: European Commission. doi:10.2790/52499 1188Pedersen, K., 2000. Exploration of deep intraterrestrial microbial life: Current perspectives. FEMS Microbiol. 
1190Peebles, M.W.H., 1980. Evolution of the Gas Industry. New York University Press,New York, NY.

1191Penner, T.J., Foght, J.M., Budwill, K., 2010a. Microbial diversity of western Canadian subsurface coal beds and 1192 methanogenic coal enrichment cultures. Int. J. Coal Geol. 82, 81-93. doi:10.1016/j.coal.2010.02.002

1193Pfeiffer, R., Ulrich, G., 2010. Chemical amendments for the stimulation of biogenic gas generation in deposits 1194 of carbonaceous material. US Pat. App. 12/751,745.

1195Pohlman, J.W., Kaneko, M., Heuer, V.B., Coffin, R.B., Whiticar, M., 2009. Methane sources and production in 1196 the northern Cascadia margin gas hydrate system. Earth Planet. Sci. Lett. 287, 504-512.

1197 doi:10.1016/j.epsl.2009.08.037

1198Polman, J., Stoner, D., Delezene-Briggs, K., 1994. Bioconversion of coal, lignin, and dimethoxybenzyl alcohol 1199 byPenicillium citrinum. J. Ind. ... 13, 292-299. doi:10.1007/BF01569731

1200Prince, R.C., Gramain, A., McGenity, T.J., 2010. Prokaryotic Hydrocarbon Degraders, in: Handbook of 1201 Hydrocarbon and Lipids. Springer Berlin Heidelberg, Berlin, Heidelberg, pp. 1669-1692.

1202 doi:10.1007/978-3-540-77587-4_118

1203Raskin, L., Rittmann, B.E., Stahl, D.A., 1996. Competition and coexistence of sulfate-reducing and 1204 methanogenic populations in anaerobic biofilms. Appl. Environ. Microbiol. 62, 3847-57. 1205Raudsepp, M.J., Gagen, E.J., Evans, P., Tyson, G.W., Golding, S.D., Southam, G., 2016. The influence of 1206 hydrogeological disturbance and mining on coal seam microbial communities. Geobiology 14, 163-175. 1207 doi:10.1111/gbi.12166

1208Reeburgh, W.S., Heggie, D.T., 1977. Microbial methane consumption reactions and their effect on methane 1209 distributions in freshwater and marine environments. Limnol. Oceanogr. 22, 1-9.

1210 doi:10.4319/1o.1977.22.1.0001

1211Rice, C. A., Flores, R.M., Stricker, G.D., Ellis, M.S., 2008. Chemical and stable isotopic evidence for water/rock 1212 interaction and biogenic origin of coalbed methane, Fort Union Formation, Powder River Basin, Wyoming and Montana U.S.A. Int. J. Coal Geol. 76, 76-85. doi:10.1016/j.coal.2008.05.002

1214Rice, D.D., Claypool, G.E., 1981. Generation, accumulation, and resource potential of biogenic gas. Am. Assoc. 1215 Pet. Geol. Bull. 65, 5-25. doi:10.1306/2F919765-16CE-11D7-8645000102C1865D

1216Ritter, D., Vinson, D., Barnhart, E., Akob, D.M., Fields, M.W., Cunningham, A.B., Orem, W., McIntosh, J.C., 1217 2015. Enhanced Microbial Coalbed Methane Generation: A Review of Research, Commercial Activity, 1218 and Remaining Challenges. Int. J. Coal Geol. 146, 28-41. doi:10.1016/j.coal.2015.04.013 
1219Robbins, S.J., Evans, P.N., Esterle, J.S., Golding, S.D., Tyson, G.W., 2016. The effect of coal rank on biogenic

1220 methane potential and microbial composition. Int. J. Coal Geol. 154-155, 205-212.

1221 doi:10.1016/j.coal.2016.01.001

1222Rooney-varga, J.N., Anderson, R.T., Jocelyn, L., Ringelberg, D., Lovley, D.R., Fraga, J.L., 1999. Microbial

1223 Communities Associated with Anaerobic Benzene Degradation in a Petroleum-Contaminated Aquifer

1224 Microbial Communities Associated with Anaerobic Benzene Degradation in a Petroleum-Contaminated

1225 Aquifer 65, 3056-3063.

1226Ross, D.J.K., Bustin, R.M., 2009. The importance of shale composition and pore structure upon gas storage

1227 potential of shale gas reservoirs. Mar. Pet. Geol. 26, 916-927. doi:10.1016/j.marpetgeo.2008.06.004

1228Rouquerolt, J., Avnir, D., Fairbridge, C.W., Everett, D.H., Haynes, J.H., Pernicone, N., Ramsay, J.D.F., Sing,

1229 K.S.W., Unger, K.K., 1994. Recommendations for the characterization of porous solids. Pure Appl. Chem.

$1230 \quad 66,1739-1758$. doi:doi:10.1351/pac199466081739

1231Rowland, S.J., Alexander, R., Kagi, R.I., Jones, D.M., 1986. Microbial degradation of aromatic components of

1232 crude oils: A comparison of laboratory and field observations. Org. Geochem. 9, 153-161.

1233 doi:http://dx.doi.org/10.1016/0146-6380(86)90065-3

1234Roy, S., Raju, R., Chuang, H.F., Cruden, B.A., Meyyappan, M., 2003. Modeling gas flow through

1235 microchannels and nanopores. J. Appl. Phys. 93, 4870-4879. doi:10.1063/1.1559936

1236Savage, P.E., 2000. Mechanisms and kinetics models for hydrocarbon pyrolysis. J. Anal. Appl. Pyrolysis 54, 109-126. doi:10.1016/S0165-2370(99)00084-4

1238Schettler, P., Parmely, C., Lee, W., 1989. Gas Storage and Transport in Devonian Shales. SPE Form. Eval. 4, 1239 371-376. doi:10.2118/17070-PA

1240Schink, B., 1997. Energetics of syntrophic cooperation in methanogenic degradation. Microbiol. Mol. Biol. Rev. 1241 61, 262-80.

1242Schink, B., Stams, A.J.M., 2006. Syntrophism among Prokaryotes. The Prokaryotes 2, 309-335. doi:10.1007/01243 $387-30742-7$

1244Schlegel, M.E., McIntosh, J.C., Bates, B.L., Kirk, M.F., Martini, A.M., 2011a. Comparison of fluid

1245 geochemistry and microbiology of multiple organic-rich reservoirs in the Illinois Basin, USA: Evidence

1246 for controls on methanogenesis and microbial transport. Geochim. Cosmochim. Acta 75, $1903-1919$. doi:10.1016/j.gca.2011.01.016

1248Schlegel, M.E., McIntosh, J.C., Petsch, S.T., Orem, W.H., Jones, E.J.P., Martini, A.M., 2013. Extent and limits 

172-184. doi:10.1016/j.apgeochem.2012.10.008

1251Schlegel, M.E., Zhou, Z., McIntosh, J.C., Ballentine, C.J., Person, M. a., 2011b. Constraining the timing of 1252 microbial methane generation in an organic-rich shale using noble gases, Illinois Basin, USA. Chem. 1253 Geol. 287, 27-40. doi:10.1016/j.chemgeo.2011.04.019

1254Schlömer, S., Krooss, B., 1997. Experimental characterisation of the hydrocarbon sealing efficiency of cap 1255 rocks. Mar. Pet. Geol. 14, 565-580.

1256Schoell, M., 1980. The hydrogen and carbon isotopic composition of methane from natural gases of various 1257 origins. Geochim. Cosmochim. Acta 44, 649-661. doi:10.1016/0016-7037(80)90155-6

1258Scott, A., 1999. Improving coal gas recovery with microbially enhanced coalbed methane. Coalbed Methane 1259 Sci. Environ. ... 89-110.

1260Scott, A.R., 2002. Hydrogeologic factors affecting gas content distribution in coal beds. Int. J. Coal Geol. 50, 1261 363-387. doi:10.1016/S0166-5162(02)00135-0

1262Scott, A.R., Kaiser, W.R., Ayers, W.B., 1994. Thermogenic and secondary biogenic gases, San Juan Basin 1263 Colorado and New Mexico - implications for coalbed. Am. Assoc. Pet. Geol. Bull. 78, 1186-1209. 1264Shimizu, S., Akiyama, M., Naganuma, T., Fujioka, M., Nako, M., Ishijima, Y., 2007. Molecular characterization 1265 of microbial communities in deep coal seam groundwater of northern Japan. Geobiology 5, 423-433. 1266 doi:10.1111/j.1472-4669.2007.00123.x

1267Silva, M.L.B. da, Alvarez, P.J.J., 2010. Handbook of Hydrocarbon and Lipid Microbiology. Springer Berlin 1268 Heidelberg, Berlin, Heidelberg. doi:10.1007/978-3-540-77587-4

1269Singh, D.N., Kumar, A., Sarbhai, M.P., Tripathi, A.K., 2012. Cultivation-independent analysis of archaeal and 1270 bacterial communities of the formation water in an Indian coal bed to enhance biotransformation of coal 1271 into methane. Appl. Microbiol. Biotechnol. 93, 1337-1350. doi:10.1007/s00253-011-3778-1

1272Singh, D.N., Tripathi, A.K., 2013. Coal induced production of a rhamnolipid biosurfactant by Pseudomonas 1273 stutzeri, isolated from the formation water of Jharia coalbed. Bioresour. Technol. 128, 215-221.

1274 doi:10.1016/j.biortech.2012.10.127

1275Smith, J.W., Pallasser, R.J., 1996. Microbial origin of Australian coalbed methane. AAPG Bull. - Am. Assoc. 1276 Pet. Geol. 80, 891-897. doi:10.1306/64ED88FE-1724-11D7-8645000102C1865D

1277Solano-Acosta, W., Mastalerz, M., Schimmelmann, A., 2007. Cleats and their relation to geologic lineaments 1278 and coalbed methane potential in Pennsylvanian coals in Indiana. Int. J. Coal Geol. 72, 187-208. 
1280Stams, A., Worm, P., Sousa, D., 2012. Syntrophic degradation of fatty acids by methanogenic communities. ... 1281 Adv. Biofuels ....

1282Stams, A.J.M., Plugge, C.M., 2009. Electron transfer in syntrophic communities of anaerobic bacteria and 1283 archaea. Nat. Rev. Microbiol. 7, 568-77. doi:10.1038/nrmicro2166

1284Strapoć, D., Picardal, F.W.F., Turich, C., Schaperdoth, I., Macalady, J.L., Lipp, J.S., Lin, Y.S., Ertefai, T.F., 1285 Schubotz, F., Hinrichs, K., Mastalerz, M., Schimmelmann, A., 2008. Methane-producing microbial 1286 community in a coal bed of the Illinois Basin. Appl. Environ. ... 74, 2424-32. doi:10.1128/AEM.02341$1287 \quad 07$

1288Strapoć, D., Ashby, M., Wood, L., Levinson, R., Huizinga, B., 2010. How Specific Microbial Communities 1289 Benefit the Oil Industry: Significant Contribution of Methyl/Methanol-Utilising Methanogenic Pathway in 1290 a Subsurface Biogas Environment, in: Applied Microbiology and Molecular Biology in Oilfield Systems.

1291 Springer Netherlands, Dordrecht, pp. 211-216. doi:10.1007/978-90-481-9252-6_25

1292Strapoć, D., Mastalerz, M., Dawson, K., Macalady, J., Callaghan, A. V., Wawrik, B., Turich, C., Ashby, M., 1293 2011. Biogeochemistry of Microbial Coal-Bed Methane. Annu. Rev. Earth Planet. Sci. 39, 617-656. 1294 doi:10.1146/annurev-earth-040610-133343

1295Strapoć, D., Mastalerz, M., Eble, C., Schimmelmann, A., 2007. Characterization of the origin of coalbed gases 1296 in southeastern Illinois Basin by compound-specific carbon and hydrogen stable isotope ratios. Org. 1297 Geochem. 38, 267-287. doi:10.1016/j.orggeochem.2006.09.005

1298Struchtemeyer, C.G., Davis, J.P., Elshahed, M.S., 2011. Influence of the drilling mud formulation process on the 1299 bacterial communities in thermogenic natural gas wells of the Barnett Shale. Appl. Environ. Microbiol. $1300 \quad 77,4744-53$. doi:10.1128/AEM.00233-11

1301Struchtemeyer, C.G., Elshahed, M.S., 2012. Bacterial communities associated with hydraulic fracturing fluids in 1302 thermogenic natural gas wells in North Central Texas, USA. FEMS Microbiol. Ecol. 81, 13-25. doi:10.1111/j.1574-6941.2011.01196.x

1304Struchtemeyer, C.G., Morrison, M.D., Elshahed, M.S., 2012. A critical assessment of the efficacy of biocides 1305 used during the hydraulic fracturing process in shale natural gas wells. Int. Biodeterior. Biodegradation 71, 15-21. doi:10.1016/j.ibiod.2012.01.013

1307Tarafa, M., Whelan, J., Mountain, G., 1987. Sediment slumps in the middle and lower eocene of deep sea drilling project holes 605 and 613: chemical detection by pyrolysis techniques. Init. Repts. DSDP 661- 
1310Trembath, A., Jenkins, J., Nordhaus, T., Shellenberger, M., 2012. Where the Shale Gas Revolution Came From. 1311 Breakthr. Inst.

1312Ulrich, G., Bower, S., 2008. Active methanogenesis and acetate utilization in Powder River Basin coals, United 1313 States. Int. J. Coal Geol. 76, 25-33. doi:10.1016/j.coal.2008.03.006

1314Unsworth, J.F., Fowler, C.S., Jones, L.F., 1989. Moisture in coal. Fuel 68, 18-26. doi:10.1016/0016$1315 \quad 2361(89) 90005-7$

1316Valentine, D.L., Reeburgh, W.S., 2000. New perspectives on anaerobic methane oxidation. Env. Microbiol 2, $1317 \quad 477-484$.

1318Vandenbroucke, M., Largeau, C., 2007. Kerogen origin, evolution and structure. Org. Geochem. 38, 719-833. 1319 doi:10.1016/j.orggeochem.2007.01.001

1320Volkman, J.K., Alexander, R., Kagi, R.I., Noble, R.A., Woodhouse, G.W., 1983. A geochemical reconstruction 1321 of oil generation in the Barrow Sub-basin of Western Australia. Geochim. Cosmochim. Acta 47, 20911322 2105. doi:10.1016/0016-7037(83)90034-0

1323Waldron, P.J., Petsch, S.T., Martini, A.M., Nüslein, K., 2007. Salinity constraints on subsurface archaeal 1324 diversity and methanogenesis in sedimentary rock rich in organic matter. Appl. Environ. Microbiol. 73, 1325 4171-4179. doi:10.1128/AEM.02810-06

1326Warwick, P.D., Breland Jr., F.C., Hackley, P.C., 2008. Biogenic origin of coalbed gas in the northern Gulf of 1327 Mexico Coastal Plain, USA. Int. J. Coal Geol. 76, 119-137. doi:10.1016/j.coal.2008.05.009

1328Wawrik, B., Mendivelso, M., Parisi, V. a, Suflita, J.M., Davidova, I. a, Marks, C.R., Van Nostrand, J.D., Liang, 1329 Y., Zhou, J., Huizinga, B.J., Strąpoć, D., Callaghan, A. V, 2012a. Field and laboratory studies on the 1330 bioconversion of coal to methane in the San Juan Basin. FEMS Microbiol. Ecol. 81, 26-42. doi:10.1111/j.1574-6941.2011.01272.x

1332Weimer, P., Zeikus, J., 1978. One carbon metabolism in methanogenic bacteria. Arch. Microbiol. 119, $49-57$. doi:0302-8933/78/0119/0049/\$01.80

1334Wellsbury, P., Goodman, K., Barth, T., Cragg, B.A., Barnes, S.P., Parkes, R.J., 1997. Deep marine biosphere 1335 fuelled by increasing organic matter availability during burial and heating. Nature 388, 573-576.

1336Wenger, L.M., Isaksen, G.H., 2002. Control of hydrocarbon seepage intensity on level of biodegradation in sea 1337 bottom sediments. Org. Geochem. 33, 1277-1292. doi:10.1016/S0146-6380(02)00116-X

1338Whelan, J.K., Farrington, J.W., Tarafa, M.E., 1986. Maturity of organic matter and migration of hydrocarbons in 
1340Whiticar, M.J., 1999. Carbon and hydrogen isotope systematics of bacterial formation and oxidation of methane.

1341 Chem. Geol. 161, 291-314. doi:10.1016/S0009-2541(99)00092-3

1342Whiticar, M.J., 1990. A geochemical perspective of natural gas and atmospheric methane, in: Organic

1343 Geochemistry. pp. 531-548. doi:10.1016/0146-6380(90)90068-B

1344Whiticar, M.J., Faber, E., 1986. Methane oxidation in sediment and water column environments-Isotope

1345 evidence. Org. Geochem. 10, 759-768. doi:10.1016/S0146-6380(86)80013-4

1346Whitman, W.B., Bowen, T.L., Boone, D.R., 2006. The Methanogenic Bacteria, Prokaryotes Vol. 3.

1347 doi:10.1007/0-387-30743-5_9

1348Whitman, W.B., Coleman, D.C., Wiebe, W.J., 1998. Prokaryotes: the unseen majority. Proc Natl Acad Sci U S A 1349 95, 6578-6583. doi:10.1073/pnas.95.12.6578

1350Widdel, F., Grundmann, O., 2010. Handbook of Hydrocarbon and Lipid Microbiology, Handbook of

1351 Hydrocarbon and Lipid .... Springer Berlin Heidelberg, Berlin, Heidelberg. doi:10.1007/978-3-540-

$1352 \quad 77587-4$

1353Widdel, F., Rabus, R., 2001. Anaerobic biodegradation of saturated and aromatic hydrocarbons. Curr. Opin.

1354 Biotechnol. 12, 259-276. doi:10.1016/S0958-1669(00)00209-3

1355Wiegel, J., Tanner, R., Rainey, F. a, 2006. An Introduction to the Family Clostridiaceae. Prokaryotes 654-678.

1356 doi:10.1007/0-387-30744-3

1357Wolin, M., 1982. Hydrogen transfer in microbial communities, in: Microbial Interactions and Communities.

1358 Academic Press London, pp. 323-356.

1359Wuchter, C., Banning, E., Mincer, T.J., Drenzek, N.J., Coolen, M.J.L., 2013. Microbial diversity and

1360 methanogenic activity of antrim shale formation waters from recently fractured wells. Front. Microbiol. 4,

1361 1-14. doi:10.3389/fmicb.2013.00367

1362Yang, L., Manno, J., Grossmann, I.E., 2014. Optimization Models for Shale Gas Water Management. AIChE J.

1363 60, 1-43. doi:10.1002/aic.14526

1364Zehnder, A.J., Brock, T.D., 1979. Methane formation and methane oxidation by methanogenic bacteria. J.

1365 Bacteriol. 137, 420-432.

1366Zhang, R., Wang, Q.H., Luo, Z.Y., Fang, M.X., Cen, K.F., 2013. Competition and Inhibition E ff ects during

1367 Coal Char Gasi fi cation in the Mixture of $\mathrm{H} 2 \mathrm{O}$ and CO 2.

1368Zhang, T., Ellis, G.S., Ruppel, S.C., Milliken, K., Yang, R., 2012. Effect of organic-matter type and thermal 
1369 maturity on methane adsorption in shale-gas systems. Org. Geochem. 47, 120-131.

1370 doi:10.1016/j.orggeochem.2012.03.012

1371Zhou, Z., Ballentine, C.J., Kipfer, R., Schoell, M., Thibodeaux, S., 2005. Noble gas tracing of

1372 groundwater/coalbed methane interaction in the San Juan Basin, USA. Geochim. Cosmochim. Acta 69,

1373 5413-5428. doi:10.1016/j.gca.2005.06.027

1374Zinder, S., 1993. Physiological ecology of methanogens. Methanogenesis 128-206. 